\title{
Ethical judgment and radical business changes: the role of entrepreneurial perspicacity
}

\begin{abstract}
This study examines the implications of practical reason for entrepreneurial activities. Our study is based on Thomas Aquinas' interpretation of such virtue, with a particular focus on the partition of practical reason in potential parts such as synesis, or common sense, and gnome, or perspicacity. Since entrepreneurial acts and actions deal with extremely uncertain situations, we argue that only this perspicacity, as the ability of correctly judging in exceptional cases, has the power to find wisdom under such blurred conditions. Perspicacity frees entrepreneurs from their cognitive schemata rendering them able to be truly entrepreneurial. Based on this vision and thanks to a semantic analysis of the meaning of the Greek word gnome, we construct an interpretative model for entrepreneurial judgment composed of three dimensions, specifically, knowledge-cognitive, external-affective, and personal-reflective. The model highlights how a 'successful' entrepreneurial judgment is also such from a holistic point of view.
\end{abstract}

KEYWORDS: Entrepreneurial perspicacity or gnome; Practical reason; Thomas Aquinas; Decision-making process; Successful entrepreneurs.

\section{Introduction}

Business ethics scholars have progressively increased their interest towards entrepreneurship and entrepreneurial actions (Novak, 1993; Cornwall and Naughton, 2003; George, 2003; Dew and Sarasvathy, 2007; Arjoon, 2008; Clarke and Holt, 2010; Melé, 2010). Virtue ethics is the theoretical lens used in a substantial number of contributions that study such phenomena; in particular, analyses of practical reason (PR), a translation of the classical concept of phronesis, or in the later Latin tradition prudentia, are largely applied (Buchholz and Rosenthal, 2005; Hartman, 2008; Dunham, 2010). Aristotle in Nicomachean Ethics (henceforth $N E$ ) regards this fundamental habitus of character as the capacity to find the proper means to reach particular ends, by interpreting the contingencies of the issue and then ordering best actions (NE, VI, 5 , 1138b24ff; Broadie, 1991; Westberg, 1994). We want to contribute to the debate about PR and entrepreneurship using the Thomistic interpretation of this virtue contained in Aquinas' principal treatise Summa Theologiae (henceforth S.Th). 
In order to understand the importance of PR in the entrepreneurial world, we may consider Schumpeter's affirmation that a fundamental characteristic of entrepreneurship is "the capacity of seeing things in a way which afterwards proves to be true, [...] grasping the essential fact, discarding the unessential" (Schumpeter; 1934, p.85). This virtue should be even sharper in leaders who need to understand best actions for themselves and at the same time for their community, i.e. their company, and for society at large, i.e. societal and stakeholders' welfare, or the common good (Freeman 1994; George, 2003; Benedict XVI, 2009; Melé, 2009). We focus our attention on changing environments, crisis moments and other circumstances where uncertainty is 'high' or rather that paradigm of such uncertainty is changing. An entrepreneurial orientation or mindset is therefore required to better respond to such situations (Penrose, 1959; Covin and Slevin, 1991; Lumpkin and Dess, 1996; Teece et al., 1997).

In many cases, these entrepreneurial actions, i.e. actions done with an entrepreneurial orientation, have a strong morphogenetic power, which is the power to deeply reshape company routines, current paradigms, and the global fit in the environment (Helfat et al., 2007). These new arrangements affect the whole company's life, for example by unbalancing equilibria in the composition of stakeholders' interests, by redefining contingent ways through which these publics can receive satisfaction, or by the emergence of completely new ethical challenges (Cornwall and Naughton, 2003). Undoubtedly, PR is the dominant virtue to face such situations, with its ability to find proper means and 'right' courses of actions (Buchholz and Rosenthal, 2005; Nonaka and Toyama, 2007; Hartman, 2008; Méle, 2009).

Nevertheless, in order to activate entrepreneurial actions, a correct evaluation and perception of the situation by leaders is necessary (Kor et al., 2007; Eggers and Kaplan, 2013). Thus we will study the judgment process and how individuals evaluate alternatives, in order to clearly define what should be the considered approach for successful entrepreneurs. We suggest the classification of PR into parts defined by Thomas Aquinas, considering specifically those related to judgment, also called potential parts, viz. synesis or common sense and gnome or perspicacity ${ }^{1}$ (NE, VI, 10, 1142aff; S.Th, II ${ }^{\text {ae }}$-IIae, q.51, a.3, a.4). Synesis informs judgment following shared, common, and accepted rules. Gnome is the mental habit which allows discernment about exceptional cases where normal rules are, to some extent, exceeded. Due to the uncertainty that is intrinsically related to entrepreneurial activities, a judgment based on a company's past 
experience, or on a collection of existing routines, may be insufficient to control and interpret all ethical questions and consequences. Thus a judgment based on common sense that correctly judges using ordinary norms and precepts may be 'blind' and lead to unexpected outcomes and possible inertial replies (Huff, 1990; Christensen and Bower, 1996). Instead gnome correctly judging controversial cases, or those which escape ordinary rules, perfectly fits entrepreneurial ontology and nature. In our interpretation, such perspicacity enacts entrepreneurial orientation (Miller, 1983; Covin and Slevin, 1991; Lumpkin and Dess, 1996) and confers moral righteousness on the actions made on the basis of such orientation.

In order to structure such claims, we offer an interpretative model of judgment based on the virtue of perspicacity or gnome by explicating its practical elements, i.e. knowledge-cognitive, external-affective, and personal-reflective dimensions. We also see that these dimensions resemble the effectuation model of action (Sarasvathy, 2001) based on three fundamental assumptions: What the entrepreneur knows, Who s/he is, and with Whom s/he collaborates. This perfectly places our model inside the body of entrepreneurial literature that can be used to frame the decision-making of leaders.

This study makes different contributions to diverse streams of literature. First, our work studies a relatively new concept in the business ethics literature, i.e. the virtue of gnome. In other branches of applied ethics (such as medical ethics and bioethical studies), analyses of this virtue already exist, especially in relation to controversial issues such as euthanasia, appropriate medical treatments etc. (e.g., Murphy, 2006). In business too there are delicate matters in relation to radical changes and crises, such as firing employees, reshaping governance structures and processes, and so on, which would require the same perspicacity.

Second, with reference to the entrepreneurial and managerial cognition literature, we add the virtue of perspicacity to the set of relevant characteristics involved in the cognitive process of judgment. Studies on this topic rarely present a strong account of ethical or philosophical implications (for a recent review, see Eggers and Kaplan, 2013). Indeed the virtue ethics has already put at a central stage the decision-making process specifically applied to business matters (e.g., Arjoon, 2008, 2010; Bastons, 2008; Grassl, 2010; Melé, 2010). Thus, we would like to stimulate a major debate between these two streams of literature. 
Third, we offer a set of practical elements organized in an interpretative model of the process of ethical judgment. Thanks to a semantic reconstruction of the meanings of gnome, we show how a 'correct' entrepreneurial judgment should be made.

Our study is articulated in five sections including this introduction. The second section is dedicated to the philosophical analysis of PR, particularly its separation into parts. Further, in the third section we explicate how perspicacity can contribute to the success of entrepreneurs because of the ability to correctly recognize exceptional business cases. The fourth section presents practical elements of the virtue of perspicacity and the interpretative model of ethical judgment. Also, we present one narrative case study from which some properties of our model may be inferred. The final section is dedicated to conclusions and limitations.

\section{Theoretical Elements of Practical Reason and its Parts}

\section{The Importance of Practical Reason}

The highest sphere of the human soul, the intellectual part, encompasses one part of pure rationality (dianoia) and the character (ethos) is the other part. The former is related to the discovery of ultimate truths and universal concepts; the latter is led by reason but is also affected by, and needs to cope with, emotions and impulses coming from the sensitive part, viz. instincts and inclinations (NE, VI, 1, 1138b18ff; Aristotle, De Anima, III, 8, 431b20ff). In relation to this division, Aristotle proposes two sets of virtues: dianoetic virtues (techne or art, nous or intellect, episteme or science, sophia or wisdom, and PR) and ethical virtues such as justice, fortitude, and temperance, that represent the cardinal virtues (S.Th, I'-IIae, q.61, a.1-5). PR has always been considered to be one of the most unique virtues due to its natural duality. Fundamentally, PR has a dianoetic or intellectual nature while its context of application is strongly orientated towards practical matters as the domain of ethical virtues (NE, VI, 5, 1140a24ff and 7, 1141a9ff). Thus, PR is neither purely contemplative as the individuation of rational universal concepts, nor purely behavioural as derived from character (S.Th, II ${ }^{\text {ae }}$-IIae, q.47, a.1, a.3-4).

In an extreme synthesis, PR is the habit of finding the right means in relation to particular moral ends. PR applies universal rules and principles to real situations in order to obtain hoped for (good) outcomes (Melé, 2010, pp.641-642). The other virtues set those particular ends (teloi), and PR renders it possible to find 'reasoned' means and courses of action to achieve such ends (NE, VI, 13, 1144a8-11; S.Th, II ${ }^{\mathrm{ae}}-$ IIae, q.47, 
Ethical judgment and radical business changes: the role of entrepreneurial perspicacity

a.6-7; MacIntyre, 1984). However, commanding rightful acts and thus perfecting actions, PR is not simply instrumental for other virtues. Indeed, PR actively contributes to perfect human purposes because 'well done' is not only about 'what' has been done but also arises from 'how' it is realized (S.Th, II ${ }^{\text {ae }}$-IIae, q.47, a.1, a.4-5).

Many scholars interpret PR as a link between ethical and dianoetic virtues (Cessario, 2002). PR confers awareness of the situation and of contingencies, orientating the ethical virtues towards the truth in order to act righteously. The awareness offered by PR is logically influenced by dianoetic virtues, which concern truth and universal concepts (NE, VI, 13, 1144b1ff; S.Th, I'-IIae, q.9, a.1; q.58, a.5; Aquinas, Commentary on the Nicomachean Ethics, lectio 11, 1275). In turn, without PR, human beings would not be able to apply to reality the universal concepts and rules derived from dianoetic virtues. These two simultaneous conditions make PR oriented towards the good and inspired by truth. Probably for all of these reasons, PR is also considered a cardinal virtue and regarded as principal above the other virtues $\left(S . T h, I^{\mathrm{a}}\right.$-IIae, q.61, a.3; Aquinas, Commentary on the Nicomachean Ethics, lectio 7, 1195 and lectio 11, 1275), and as the one most needed for human life (S.Th, I'-IIae, q.57, a.5).

\section{Integral and Subjective Parts of the Virtue of Practical Reason}

Beyond the general and recognized importance assigned to PR in business matters (Hartman, 2008; Dunham, 2010), there is a good body of recent works that specifically uses the Thomistic framework (e.g. Arjoon, 2008; Melé, 2009; Argandoña, 2011; Melé et al., 2011; Acevedo, 2012; Sison and Fontrodona, 2012). However, Aquinas' framework is still underestimated, especially in studies of managerial or entrepreneurial cognition (for a review see Huff, 1990; Walsh, 1995; Kor et al., 2007), even if some studies have applied it to the decision-making process (Bastons, 2008; Arjoon, 2010; Grassl, 2010; Melé, 2010).

In order to highlight the contributions that such interpretations can make to this debate, we need to deepen the philosophical analysis of PR. Aquinas recognizes that clustered around PR, as for the other cardinal virtues, a significant variety of other minor virtues is either integrated into or connected with the principal virtue (S.Th, II ${ }^{\text {ae }}$-IIae, q.48, a.1; Bradley, 1997). This bundle of virtues, in Aquinas, is organized according to the medieval precepts of mereology, which is a branch of philosophy completely dedicated to the wholeparts relation (Arlig, 2011). Aquinas' categorization follows the ancient tradition started by Boethius in De 
Divisione, who recognized that a whole can be formed or divided into parts, and that depends on its nature as an integral, universal, or potential whole ${ }^{2}$.

Integral parts are essential components of a whole, for example a house is made of a roof, walls and doors. In turn, the integral whole would cease to exist as a whole without such components. Aquinas talks about integral parts of PR as being essential and characteristic activities or psychological dispositions in order to accomplish the proper act of the principal virtue (S.Th, II ${ }^{\text {ae }}$-IIae, q.48 a.1; Bradley, 1997; Cessario, 2002). For these reasons, such integral parts of a virtue cannot be separated from it, inasmuch as an organ of a living being is not a living being in autonomy, nor can it operate without the whole. With respect to PR, integral parts individuate eight minor virtues: memory, understanding or intellect, docility, shrewdness, and reasoning regarded as cognitive components; foresight, circumspection, and caution regarded as normative (S.Th, II ${ }^{\mathrm{a}}$-IIae, q.48, a.1, q.49, a.1-8).

Universal wholes are referred to as sets of genera and species (differentiae) in which such universal concepts can find expression, and these expressions are called subjective parts (S.Th, Ia, q.8, a.2). For example, individuals are subjective parts of the universal whole, a species, in this case, of human beings. The same can be said about all other genera of animals, e.g. horses, lions, etc., which constitute the universal whole 'animal'. A marked difference with regard to integral parts is the 'cohesion' of this subjective category. If subjective parts in reality ceased to exist, for example through the extinction of a species, the universal whole itself would not perish (Arlig, 2011). Also, an integral part represents only the part that it composes inasmuch as a hand is not a whole human being. The same sense cannot be grasped in relation to subjective parts because a lion is an animal as much as a human is. In discussing the subjective parts of PR, Aquinas states a primary division between a PR dedicated to self-governing and to governing of the multitudes. Regarding the latter kind of PR, other categories are highlighted: regnative PR when the multitudes represent cities or kingdoms from the perspective of the governor; political PR refers to the same multitudes but from the perspective of the subjects being governed; domestic PR is the application of such virtue to groups bonded for life, such as a family; and military PR is the virtue to governs a multitude bounded for a purpose, such as an army (S.Th, II ${ }^{\text {ae }}$-IIae, q.48, a.1; q.50, a.1-4).

\section{Potential Parts of the Virtue of Practical Reason}


Ethical judgment and radical business changes: the role of entrepreneurial perspicacity

Finally PR can be considered as a potential whole and so formed by potential parts. Boethius (De divisione, 888a) talks about wholes being composed of 'powers' (potentiae), which are not separable, while at the same time a differentiation can be made based on the functions of the potential parts. Potential parts are allied to the whole to express its full potency, and for this reason they are also called virtual parts as opposed to actual or integral parts (Aquinas, Commentary on Aristotle's De Anima, lectio 4-5, 262-298). As a master example of a potential whole, the human soul is often used. The soul is one and indivisible but at the same time is composed of parts, viz. vegetative, sensitive, and intellectual (Aristotle, De Anima, II, 3, 414a28ff). The vegetative part governs survival and procreation functions as exist in all living creatures: plants, animals and human beings; the sensitive part, which is shared by animals and human beings, directs impulses and sensible stimuli received from the external world; and the rational or intellectual part (dianoia and ethos) is the prerogative only of the human species if the immaterial or spiritual world is not considered (S.Th, Ia, q.78, a.1-4). As with subjective wholes, without some potential parts the whole still exists but a potential whole without one of its potential parts loses some of its power and cannot be considered as complete, similarly to what happens with integral wholes (S.Th. Ia, q.3, a.7; Arlig, 2011).

About virtues Aquinas says that potential parts can occur even without the principal virtue, because they are virtues themselves, but they cannot reach the perfection of the whole as this is a specific quality of the principal virtue. Using his words:

"The potential parts of a virtue are the virtues connected with it, which are directed to certain secondary acts or matters, not having, as it were, the whole power of the principal virtue [...] the parts of prudence [i.e. practical reason] are: 'good counsel' which concerns counsel, 'synesis' which concerns judgment in matters of ordinary occurrence, and 'gnome', which concerns judgment in matters of exception to the law" (S.Th, II ${ }^{\mathrm{ae}}-$ IIae, q.48, a.1, respondeo).

Specifically, good counsel or euboulia is dedicated to well-researched means of actions or well-advised investigation to find convenient and appropriate means for human purposes (S.Th, II ${ }^{\mathrm{a}}$-IIae, q.51, a.1-2). Common sense or synesis informs judgment following shared, common, and accepted rules in ordinary cases (S.Th, II ${ }^{\text {ae }}$-IIae, q.51, a.3); and perspicacity or gnome, which may be translated also as sharp-sightedness, sense of exceptionality, or maybe farsightedness is the mental habit which allows discernment about particular cases where normal rules are exceeded, i.e. in extraordinary or exceptional cases (S.Th, I'-IIae, q.57, a.6 and II $^{\text {ae }}$-IIae, q.51, a.4). 
Ethical judgment and radical business changes: the role of entrepreneurial perspicacity

These cases are considered to be 'extraordinary' because of their complexity, where it is necessary to go beyond the simple surface of the order of reality and discover what truly lies beneath. Gnome makes possible the application of such superior principles as equity and epikeia which moderate and guide the use of norms in order to obtain fairer and better results. Gnome may be seen as a 'trigger' of equity and epikeia due to the fact that they can act only when the agent is aware of being in front of a special situation. Simple application of rules would lead to injustice rather than justice, to evil instead of good (Cajetan, Commentarius Summa Theologiae q.120; Rodríquez-Luño, 1997).

Gnome is also the ability to identify positive or civil law's domain of application (S.Th, I'-IIae, q.57, a.6 and II $^{\text {ae }-I I a e, ~ q .51, ~ a .4 ; ~ W e s t b e r g, ~ 1994-1995) . ~ C i v i l ~ l a w ~ c a n n o t ~ c o v e r ~ e v e r y ~ e v e n t u a l i t y ~ o f ~ r e a l i t y, ~ s o ~ d o u b t f u l ~}$ situations may arise, i.e. exceptional cases. An example is when the application of rules is not able to explain reality or clashes with the final scope of the law. In such situations, 'wise' judges avoid strict adherence to common, established, and shared rules that are contained in civil law, in order to make reference to major principles as equity contained in natural law. Thus, the correct judgment for such exceptional cases cannot be made using the virtue of synesis that judges well according to common and shared rules. Rather, this judgment should be assessed using the virtue of gnome that judges well where higher principles of soul and natural law must be applied (Cajetan, Commentarius Summa Theologiae q.51, q.120; Rodríquez-Luño, 1997; Cessario, 2002).

The partition of PR into parts is shown in figure 1.

Figure 1 ABOUT HERE

Concerning the relationship between PR and its potential parts, distinctions should be drawn according to acts and activities of competence (Bradley, 1997; Cessario, 2002). Aquinas states that three acts contribute to the perfect or complete action of PR: counsel, judgment, and command (consiliari et iudicare et praecipere or imperare) (S.Th, I'-IIae, q.57, a.6 and $\mathrm{II}^{\mathrm{ae}}-$-IIae, q.47, a.8, a.10, q.48, a.1). In the first step, the inquiry begins with the search for available means and alternatives. In a second moment, individuals evaluate the 
appropriateness of such means for achieving a particular end, and in the final instance, command and precept are invoked to instruct an action (NE, VI, 11, 1143a8-11).

If $\mathrm{PR}$ is the right reason applied to action, command is its principal act (principalis actus rationis practicae), while the other activities are assigned to its potential parts, respectively euboulia and synesis or gnome (S.Th, II $^{\text {ae }-I I a e, ~ q .47, ~ a .2, ~ a .8 ~ a n d ~ q .51, ~ a .1, ~ a .3-4 ; ~ C a j e t a n, ~ C o m m e n t a r i u s ~ S u m m a ~ T h e o l o g i a e ; ~ q .47) . ~}$

Aquinas considers command as the principal act over the others because this is what makes men truly virtuous. A person can be extremely good at advising others, as with the possession of euboulia, but then fails to go beyond that point, displaying a lack of PR and command (S.Th, I'-IIae, q.57, a.6, II ${ }^{\text {ae }}-$ IIae, q.48, a.1, q.51, a.1-4, q. 53, a.4). This can also be said of a person who can cleverly interpret and judge situations, i.e. one who correctly applies the virtue of synesis or gnome, but then performs careless actions or disorganized deeds, thereby also showing a lack of PR (S.Th, I'-IIae, q. 53, a.3, a.5; Cessario, 2002). Thus, good advice and sound judgment must be conveyed into 'reasoned' deeds that are led by command and PR (Westberg, 1994). Despite this, Aquinas also highlights that perfect actions of PR cannot be so if the other potential parts are inadequately developed. He explains this condition by using the parallelism of potential parts of the human soul. The intellectual part of the soul (dianoia and ethos) could not exist and be perfect if the vegetative and sensitive parts did not exist or stopped guiding the more basic human functions (S.Th, Ia, q.78, a.1-4). To summarize, if on the one hand potential parts of PR are just qualities, limited in their intent, on the other hand, PR is perfect when its potential parts also intervene to instruct the action.

\section{Gnome and Synesis: Different Approaches to Judgment}

As mentioned before, acts of judgment correctly involve the use of gnome or synesis depending on the situation (S.Th, II ${ }^{\mathrm{a}}$-IIae, q.51, a.3-4). However, we need to clearly highlight when this step takes place inside the whole action process. To this end, we used Aquinas' model of action according to Westberg's interpretation (1994, p. 119ff). It considers every human action as articulated in four stages, each of which occurs as a results of the dynamic interaction of intellectual and volitional aspects (S.Th, I'-IIae, q.9, a.1-6) (given in parentheses): intention (apprehensio and intentio) (S.Th, I ${ }^{\mathrm{a}}$-IIae, q.12, a.1-5), deliberation (consilium and consensus) (S.Th, I'-IIae, q.14, a.1-6, q.15, a.1-4), decision (judicium and electio) (S.Th, I'IIae, q.13, a.1-6), and execution (imperium and usus) (S.Th, I'-IIae, q.16, a.1-4, q.17, a.1-9). We will follow 
Aquinas' model in explaining the practical and entrepreneurial applications of perspicacity and common sense.

\section{The Decision Stage: the Step of Judgment and of Choice}

The decision stage or decision-making process in managerial terms is formed by two consequential steps: the judicium (the judgment) and the electio (the choice). In Aquinas, the first aspect is specifically understood as iudicio electionis (judgment of election) (S.Th, I'-IIae, q.13, a.1), which in managerial terms we may see as the perception and evaluation of the alternatives available in order to solve a problem. The following step is the real choice of, and the final decision about, presumably the best solution (electio). However, this latter step is the inclination of will towards the specific object of judgment and, under specific conditions such a moment, already belongs to the command act (S.Th, Ia, q, 82, a.1-4, q.83, a.1-4 and I'-IIae, q.13, a.1-2, q.16, a.1; Bradley, 1997). Indeed, all nuances of the command process should be ascribed to the principal act of PR (Cessario, 2002).

Thus, inquiring only about the evaluation of the alternative or step of judgment and excluding the real choice or final decision is correct, at least in the light of two perspectives. Philosophically speaking, only the aspect of judgment can be directly and exclusively related to considerations concerning synesis and gnome. Instead, including the choice would necessarily involve facets related to the principal virtues of PR.

Secondly, managerial literature specifically dedicated to the cognitive approach suggests that marked differences among leaders' decision-making processes may be found during the evaluation of alternatives rather than in the final decision (Huff, 1990; Walsh, 1995; Kaplan, 2008). Some leaders are able to free themselves from their previous mental schemata, judging according to higher principles that waive the current paradigm. We will call such leaders 'successful' entrepreneurs because they can change their strategic action due to the acumen of their judgment. In contrast, other leaders have a strong cognitive resistance to change led by cognitive frames stuck in an old understanding of the environment. Such a condition bounds their judgment, reducing options about what can be done (D'Aveni and MacMillan, 1990; Huff, 1990; Christensen and Bower, 1996; Eggers and Kaplan, 2013). We argue that both discerning and being aware of 'exceptional' cases, those that escape 'normal' rules, represent the first step in successfully replying to and anticipating conditions that change (Kirzner, 1973). 


\section{The Emergence of Entrepreneurial Orientation}

In turbulent contexts, contingencies of business suddenly and frequently change, and such stimulations require a company's leaders to pay attention to weak signals, as to give concrete replies (Teece et al., 1997). Changeable and uncertain circumstances, at certain points, may make companies' current routines, traditions or approaches unsuitable. In particular, the strategic management literature addresses this topic with the introduction of the concept of dynamic capabilities, which are learning processes that allow the reconfiguration of resources, knowledge and competences (Teece et al., 1997).

A substantially flexible approach to the environment may be also required in order to grasp or create new opportunities in the market and to structure new paths of growth. Consequently, the entrepreneurship literature talks about entrepreneurial orientation as entrepreneurial processes, methods, practices, and decision-making styles used by leaders to act entrepreneurially (Miller, 1983; Covin and Slevin, 1991; Lumpkin and Dess, 1996, p. 136) ${ }^{3}$. Despite the fact that dynamic capabilities and entrepreneurial orientation refer to the companies and their behaviour, the initial kick-start for such processes should be made in leaders' minds (Huff, 1990; Walsh, 1995). Leaders try to match their mental images of the environment and perceptions of opportunities with the action of the company, thus ultimately, dynamic capabilities and entrepreneurial orientation are enacted by leaders' perceptions and evaluation of alternatives (Penrose, 1959; Kor et al., 2007; Eggers and Kaplan, 2013). This connection validates the possibility of studying the personal dispositions of leaders, in relation to companies' outcomes and performance.

A central topic of the managerial and entrepreneurial cognitive body of studies is to understand and discover constrains to change. Knight (1921) explains that environmental changes and uncertainty are not crucial points per se; rather, leaders are unable to assess what those contingencies really mean and which might be consequential (Walsh, 1995; Kaplan, 2008). In this work, particular attention is paid to misleading individual behaviours - those that drive the misleading strategic actions of the company - that are related to leaders' judgment processes (Starbuck et al., 1978; Thaler, 2000). Leaders' perceptions about opportunities and the environment affect their judgment, e.g. feasible alternatives are weighted in different ways in relation to perceived constraints (Gifford, 1992; Dew et al., 2009). Thus, leaders can fail to judge correctly due to their cognitive biases about contingencies (Huff, 1990). Judgment results are wrong and ill-directed because of the 
Ethical judgment and radical business changes: the role of entrepreneurial perspicacity

particular circumstances - that need different approaches - rather than the absolute unreasonableness of the applied criteria of judgment (Kaplan, 2008). For example, procrastination on applying ordinary routines and past successful strategies during moments of radical changes in the market fails to redirect the strategic action of a company (D’Aveni and MacMillan, 1990; Christensen and Bower, 1996). As Nonaka and Toyama (2007, p. 379) suggest, successful leaders firstly 'see' and 'feel' problems, then are properly able to act.

So, the judgment, either with the use of common sense or perspicacity, ends by offering an 'image' or scenario for each alternative, basically positive or negative. When in business life a 'normal' or ordinary case is recognized, the judgment may be properly based on present paradigms and routines, as a judgment assessed on the basis of common sense. In contrast, the existing situation may be considered as an 'extraordinary case', and so the disapplication of actual paradigms and the activation of actions made with an entrepreneurial orientation may be positively evaluated, as a judgment assessed on the basis of perspicacity. Hence, in conclusion, before acting in a revolutionary way, leaders need to understand that dynamic capabilities or entrepreneurial orientation are the best solutions to face those contingent circumstances.

\section{The Ability of Perspicacity and Common Sense to Frame Radical Changes}

In order to explain in business terms how judgment based on gnome or synesis may work, we use some examples drawn from the literature. Christensen and Bower's study (1996) shows the failure of established disk drive producers during the expansion phase of the PC during the1980s. The reason for the collapse was a limited innovation trajectory, completely structured on clients' base claims, i.e. large computer factories of that time. At the beginning of the digital era, the market for computers was mainly dominated by mainframes, while small computers to be used at home (PCs) were regarded as nothing more than toys with a limited market (Christensen and Bower, 1996). Consequently, under pressure from computer companies, the $\mathrm{R} \& \mathrm{D}$ activities of disk drive producers tended to continuously increase the storage space of their devices. However, such a focus rendered leaders of established companies in the disk drive industry unable to 'see' the emergence of the new market of the floppy disk associated with the use of PCs.

Another example is the one offered by D'Aveni and MacMillan (1990) on crisis management and attention from CEOs during this same period. Their results revealed that in companies which survived a crisis, their 
leaders were more external oriented in order to grasp every possible signal from external environments. In contrast, in failed companies, leaders concentrated their attention on internal information.

It can be seen that similarities exist between the two cases. First, both situations deal with uncertainty; on the one hand the opening of the new market of floppy disks, and on the other hand a crisis phase of established companies. Second, without a doubt we can assert that the companies' reactions and those of their leaders were reasonable in a general sense but unfounded in the particular situation. Abstracting from these circumstances, listening to clients' claims, as in the first example, and taking into consideration internal information, as in the second one, can be considered good managerial practices, i.e. general rules that should be followed. Nevertheless, in such cases, these conducts reveal themselves to be absolutely misleading for the companies' behaviours leading to failure. Rather, successful leaders adopted almost counterfactually strategies with a disapplication of ordinary paradigms and their common way of 'feeling'. In the examples, leaders decided to go against past experience and routines, for example disregarding the reasonable expectations of their stakeholders. However, by following this path, successful leaders have saved the whole firm system, thus assuring new forms of stakeholders' satisfaction.

We can see a parallel between the cases chosen from the literature and what we presented in the philosophical part. Gnome is the ability to switch from a judgment based on the present paradigms and rules to higher principles. In our cases listening to clients and taking into consideration information coming from the internal environment were the basic principles, while saving the whole company system was at a higher level. Evaluating as positive the disapplication of current paradigms, perspicacity allows appropriate companies' replies i.e., actions made with an entrepreneurial orientation. Thus, judgment based on gnome has a deeper level of consciousness and wisdom by grasping all possibly ethical implications. Instead, judgment based on synesis misses the sense of exceptionality that allows for a reconfiguration of paradigms ${ }^{4}$. Indeed synesis leads the judgment with the maxima 'what happens in most cases' (id quod plerumque accidit), while radical changes or exceptional cases are fewer in number and constitute a 'rare' material that escapes the normality (Cajetan, Commentarius Summa Theologiae, q.51, q. 120). Thus, the application of common sense, in situations of radical change, seems to lead to less dynamic replies or even to inertia (Huff, 
1990; March, 1991; Christensen and Bower, 1996; Eggers and Kaplan, 2013). Our discussion is summarized in figure 2.

\section{Figure 2 ABOUT HERE}

\section{Entrepreneurial Perspicacity or Gnome}

\section{The Application of the Virtue of Perspicacity to Entrepreneurial Contexts}

In the light of the previous considerations, we define 'successful entrepreneurs' to be those leaders who are able to correctly understand when routines and paradigms need to be changed, or partially disregarded, and recognize this as a major benefit for the survival of the company and its continuing prosperity. However, such survival and prosperity can only be achieved if the company acts instrumentally to create 'welfare' and contributes towards the common good for society and a large number of stakeholders.

We will regard these individuals as successful entrepreneurs to highlight the difference between them and the general term leaders. This concept of 'success' is holistic because we assumed that the judgment made on the basis of perspicacity is a 'trigger' of correct entrepreneurial orientation, which in turn is related to economic performance. As a matter of fact, many studies have already pointed out how entrepreneurial orientation can lead to higher firm performance (e.g. Miller, 1983; Covin and Slevin, 1991; Lumpkin and Dess, 1996; Rauch et al., 2009; Covin and Lumpkin, 2011).

In particular, the successful entrepreneur is a virtuous person who better interprets and judges situations in a novel way (Novak, 1993). Even assuming that leaders have the same levels of moral standards, or of even other characteristics, successful entrepreneurs will produce higher value compared with their peers who have not developed this habit (Sternberg, 1990). Thus, successful entrepreneurs show a PR more directed during the judgment by perspicacity, that allows an approach to reality more fitting to the circumstances ${ }^{5}$.

This consideration is even more true if we consider that successful entrepreneurs have understood that their success is as such only if they can deliver social and common good through their company, otherwise any kind of success would be only ephemeral (Goodpaster, 2011; Melé et al., 2011). 
Ethical judgment and radical business changes: the role of entrepreneurial perspicacity

Thus, this concept of 'success' recomposes the ethical dimension of acting from an economic perspective, because the ultimate goal of the company - the contribution towards common good - is the mandatory objective of both (Cornwall and Naughton, 2003). In considering the equally important roles of ethics and economics in relation to the welfare of the company, its stakeholders and society, we assume a position similar to that expressed by the Encyclical letter Caritas in Veritate $^{6}$ (Benedict XVI, 2009).

Before moving on to explain the model of judgment on the basis of perspicacity, we need to make some minor clarifications to the application of such virtue in an entrepreneurial context. First, gnome seems hard to practise because 'exceptional cases' occur on rare occasions. Similarly to other minor virtues connected with the cardinal virtues of fortitude, such as magnanimity and as magnificence, they can be practised only in extreme and excessive circumstances, but nevertheless they are important to guide human actions $\left(S . T h, \mathrm{II}^{\mathrm{ae}}-\right.$ IIae, q.129, a.1-2, 134, a.1-3). However, considering the business life of the last few decades, radical changes in the market have always occurred at an increasing rate. Thus, in this historical moment, perspicacity is not relegated to hypothetical situations but it represents, although not sufficiently, a necessary virtue for entrepreneurship.

Second, as with any other virtue, gnome is not an inclination given by nature but it must be practised. This means that simply being exposed to entrepreneurial activities is not enough for developing perspicacity. Becoming an expert in such a 'skill' requires considerable effort, so only some individuals will take this step, despite their experience and tenure as leaders (Starbuck et al., 1978; Krueger, 2007). Leaders must be engaged in the process until such behaviours become habitual for their character. Thus, from this perspective we may see virtues, in our case, perspicacity, as 'deliberate practices' towards the right medium (Ericsson and Charness, 1994). In philosophical terms, gnome can be virtually acquired studying past 'exceptional cases' and from an effort to continuously improve discernment of reality and probably the same can be said in an entrepreneurial context (Cajetan, Commentarius Summa Theologiae, q.51).

A third aspect to clarify is the relation between gnome and PR regarding entrepreneurial behaviours. We are not arguing that autonomously perspicacity renders leaders' actions rightful. We showed in the philosophical part that gnome, and synesis, are only 'virtually' practical (S.Th, I'-IIae, q.13, a.1-2); PR is needed to complete the action. Entrepreneurial orientation and related practical actions have greater implications and 
Ethical judgment and radical business changes: the role of entrepreneurial perspicacity

complications than the simple process of judgment (Covin and Slevin, 1991; Covin and Lumpkin, 2011). Due to this complexity, PR is the only virtue able to find the proper means and the right course of action for this matter (Buchholz and Rosenthal, 2005; Nonaka and Toyama, 2007; Hartman, 2008; Méle, 2009). Gnome being only a (potential) part of PR cannot be a panacea for entrepreneurship; thus to be confident of success in every aspect of business life, it is not just about recognizing when to 'break the rules' and acting consequentially. Nevertheless, our contribution highlights that perfect PR is instructed by a reasoned judgment (S.Th, II ${ }^{\mathrm{a}}$-IIae, q.48, a.1-4) that in uncertain contingencies must be exerted with perspicacity.

Finally, gnome and synesis do not exclude each other; rather they exist in the same person forming a complete moral judgment. In personal or business life, ordinary and exceptional cases will always exist and consequently gnome and synesis must simultaneously exist too. We do not want to channel the erroneous idea that judgment based on synesis is generally a 'wrong' way to judge situations. We simply suggest that under extremely uncertain conditions, this judgment is incomplete and not deep enough to grasp all possible ethical implications. Thus from an entrepreneurial point of view, it seems that in the composition of PR as a potential whole, perspicacity needs to play a prominent role to achieve a lasting prosperity of the firm. On the other hand, judgment based on perspicacity may be inappropriate when ordinary situations are faced. If disapplication of rules and paradigms is not necessary, perspicacity could even be harmful. However, against this possible interpretation, Aquinas himself asserts that being able to judge extraordinary cases is a sign of profound wisdom and this condition renders it easier to assess every eventuality (S.Th, II ${ }^{\mathrm{a}}$-IIae, q. 51, a.4). In relation to this consideration, it seems relevant to assert that gnome self-discerns the correct border of its domain thanks to a deeper understanding of what lies beneath the surface of every situation (Cessario, 2002).

\section{Semantic Reconstruction of the Concept of Gnome}

For the sake of parsimony, hereafter we refer to 'entrepreneurial gnome or perspicacity' as the ability to detect correctly exceptional cases and in turn to correctly enact the entrepreneurial orientation process. Theoretically speaking, we have already explained why entrepreneurial perspicacity can express the expertise of successful entrepreneurs. Here, we want to identify some practical elements of this virtue and how this judgment can work. Practical implications can be deduced from an accurate semantic analysis of the definition of gnome. 
Despite the fact that for this work we only employed the interpretation of Aquinas of the virtue of gnome, in the semantic analysis for several reasons we preferred to make reference to Aristotle's original text, rather than to Aquinas' treatise. First of all, working on the Aristotelian concept renders our analysis similar to the interpretation that Aquinas may have used to elaborate his own concept. Aquinas probably had a wide range of possibilities to interpret the word gnome, but all were derived from the Biblical Greek because Latin did not have a really 'direct' translation. This situation may also be inferred by reading the original text of Aquinas; for the potential parts of PR he used transliterations, while for other concepts well-established in the Latin language tradition, translations are employed, e.g. for some of the integral parts of PR. Second, Aristotle's work was the main reference of the Aquinas interpretation, especially regarding the virtue of PR (Westberg, 1994). Finally from a practical perspective, by working on the original Biblical Greek text, we avoided large losses of semantic contents in the multiple translation process, i.e. from Greek to Latin, from Latin to modern European languages, and for those different from English, a further round of translation.

Commentators and translators of Biblical Greek manuscripts have agreed that gnome has a complex meaning, also in relation to its derivations. For example, Rackham (trans., Aristotle, ed.1968) clearly assesses that meanings of this set of words ranges from 'judgment', 'good judgment', 'well-judging' in sense of considerate and kindly, or to 'judgment with'. Furthermore, in some languages, i.e. modern Italian and Spanish, gnome has assumed new and different interpretations from the original concept. Gnome in such languages means an experiential dictum, while the word is probably related to the capacity of producing these kinds of dicta as suggested by Natali (trans. Aristotle, ed.1999). The unclear translation of gnome may hinder its pragmatic use; thus, we have assessed a semantic analysis of the passage that explicates gnome in Aristotle's treatise (NE, VI, 11, 1143a19-24). Table 1 is a comparison of gnome and its derivatives (syngnomonas, echein [...] gnomen, syngnomonikon, and sygnome(n)) in 20 contributions either in the English, French, German, Italian, or Spanish language. Thanks to this deep semantic analysis performed with the strong support of expert translators ${ }^{7}$, we have reconstructed some meaningful classes of elements, that we have called dimensions, in order to form our interpretative model of the step of judgment. 
The Three Dimensions of Perspicacity: Knowledge-cognitive, External-affective, and Personal-reflective In table 2 we reported three classes of meanings that emerged from the semantic analysis. Each of them represents one dimension of our model, which explains the process of a judgment made on the basis of entrepreneurial perspicacity ${ }^{8}$.

\section{Table 2 ABOUT HERE}

First of all, perspicacity, similarly to PR, is intimately tied to an aspect related to knowledge, with expressions such as discernment, distinction, judgment, and reason mainly assigned to the Greek word gnome $(\gamma v \omega \mu \eta)$. The virtue of gnome in this facet displays a deeper understanding, a conscious discernment of what the contingencies of life are. Indeed, a very sensible, discriminating judgment is needed to distinguish what should be treated in ordinary and common ways from what necessitates a more accurate comprehension. Despite similarities with PR, here the final scope of such knowledge is not action but the evaluation of alternatives, perfecting only the modus operandi of judgment. Thus, this dimension effectively signals the relevant elements that should be taken into consideration during moral reasoning (Hartman, 2008). Peculiar characteristics to this dimension are: its nature that seems to be more related to the purely rational part of the soul (dianoia); its contents that are related to categories of possibility and impossibility (aletheia, truth); and its focus that is oriented towards initial hints elaborated from the alternatives. In a managerial fashion, we can say that this aspect approaches reality interpreting weak signals so that successful entrepreneurs become aware of the 'prodromes or initial symptoms' of change (Kirzner, 1973; Kor et al., 2007). We considered this dimension to be a knowledge-cognitive dimension.

The second aspect is related to the word sygnome, either nominative or accusative cases $(\sigma v \gamma \gamma v \omega \mu \eta / \sigma v \gamma \gamma v \omega \mu \eta v)$. Different translations depict this concept as: compassion, consideration for others, forgiveness, indulgence, mercy, and sympathy. The virtue of gnome in this dimension demonstrates a 'caring' aspect regarding other people, a connection to an external dimension of judgment (Alberti, 2008). This 
Ethical judgment and radical business changes: the role of entrepreneurial perspicacity

distinction reveals perhaps the most marked difference between judgment made using perspicacity or common sense, because the latter has less power to trigger equity and epikeia that fundamentally are dispositions towards others (Rodríquez-Luño, 1997).

This dimension has almost complementary peculiarities to the previous one: its nature seems to be more related to the affective part of the soul (ethos), its contents are more ethical in nature, and its focus is oriented towards outcomes especially the 'gut' feeling that the outcomes of each alternative invoke in the agent who needs to judge. In a managerial fashion, this dimension lets entrepreneurs 'feel' the problem and not simply be aware of its connotations (Nonaka and Toyama, 2007). Thus, the process of evaluating alternatives is enlarged and takes into consideration together the prompts and sensations about outcomes. For all these reasons, this aspect is a component of the moral sensitivity (Haidt, 2001; Buchholz and Rosenthal, 2005) and we call it the external-affective dimension of the virtue of perspicacity.

The third bundle of terminologies inquires about a personal dimension of this accurate judgment based on

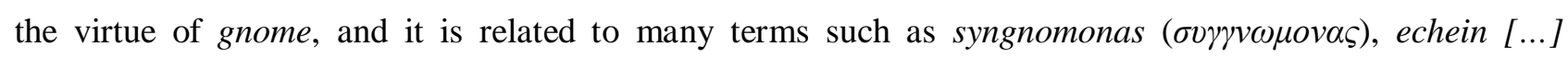

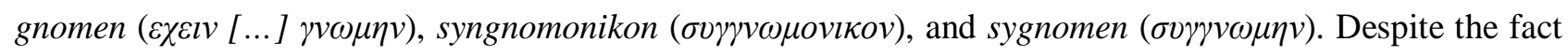
that all of these meanings refer to a habit possessed by individuals, this dimension is not homogeneous like the others, but markedly different orientations can be seen.

One orientation is devoted to the self of who judges, in our case the entrepreneurs, how to handle deeper levels of knowledge about the judgment i.e. input coming from the knowledge-cognitive dimension. This personal ability to judge, mainly contained in the first two words, is regarded as: be(ing) considerate, (being) discrete, have(ing) discretion, have(ing) right judgment, (being) judicious, reasonable men and wise. The other orientation, however, is devoted to instructing the self of the subject who is evaluating, in relation to the ability to 'sense' other people's expectations, desires and feelings. This orientation regulates the ways in which the evaluating subject becomes connected to others and pushes towards developing a sense of caring for the external environment. The other terms of this dimension received translations such as: be(ing) sympathetic judges, benign, disposed to exercise kind consideration, have(ing) forgiveness, be(ing) able to show proof of kindness, (being) well-intentioned. 
These two orientations neither state the level of knowledge of the judgment that is considered in the first dimension, nor the disposition towards the other that is considered in the second dimension of our composition of the virtue of perspicacity. Instead, the two orientations of the last dimension recompose the whole judgment process into a personal and perspicacious vision of the reality as it is. The personal dimension seems to emulate the 'hybrid' nature of the principal virtues of PR, balancing the more rational part of judgment (knowledge-cognitive dimension) with the more sensitive part (external-affective dimension), as much as PR does in relation to the dianoetic and ethical virtues. Thus, this dimension perfects the action of judging alternatives to channel clues and signals coming from a blurred reality, a 'gut' feeling about the outcomes of each of the available alternative, and the personal reinterpretations of both. Hence, the personal dimension seems to be the embodiment of moral imagination (Carroll, 1980; Buchholz and Rosenthal, 2005). We could also call this component the personal-reflective dimension.

All these dimensions may potentially be regarded, following the medieval precepts of mereology, as the integral parts of gnome. Thus, without all of them there is no judgment based on gnome (Boethius, De Divisione, 880a).

Our interpretative model states that the judgment of alternatives (iudicio electionis) begins with moral reasoning. The knowledge-cognitive dimension scans initial symptoms, weak signals, and hints coming from the circumstances in order to establish an 'alarm system' in the minds of the entrepreneurs, especially if deviations from 'normality' are detected. Indeed, this is a moment of moral reasoning. Then, successful entrepreneurs become 'sensible' to the problem, with the intervention of the external-affective dimension. This moment of moral sensitivity comprises feelings that entrepreneurs mature regarding possible alternative's outcomes, especially in relation to stakeholders' welfare and the production of a common good. At this step, the initial judgment, mainly rationality based, is enriched by feelings of appreciation or uneasiness in relation to potential outcomes of each alternative. In doing that, entrepreneurial judgment becomes 'responsible' and 'human', a fundamental trait required of a fair and successful entrepreneur' (Cornwall and Naughton, 2003). Finally, in a very personal way, entrepreneurs elaborate interpretations about conjectures and feelings acquired during previous steps. This ability concludes the process of judgment and imagines multiple and flexible scenarios for the set of alternatives, a fundamental process of what 
Carroll terms moral imagination (1980, p. 9). With these final scenarios given by the personal-reflective dimension of perspicacity, successful entrepreneurs will be able to understand correctly any uncertainty of the circumstances, and if the case requires it, will disregard current paradigms of action and engage in processes of entrepreneurial orientation. Figure 3 visualizes the formation of a judgment based on entrepreneurial perspicacity.

Figure 3 ABOUT HERE

However, again we highlight that perspicacity only confers the perfect 'frame', the light under which alternatives should be judged whereas the whole entrepreneurial action, i.e. actions done with entrepreneurial orientation, are the domain of PR.

\section{Entrepreneurship Studies and Entrepreneurial Perspicacity}

We want to ground our analysis of entrepreneurial perspicacity in the entrepreneurship literature in order to validate our model. To do this, we have taken into account works of entrepreneurial ethics that have the process of judgment as their central issue.

Buchholz and Rosenthal (2005, p. 308-309) regard flexibility in moral judgment - which is not moral relativity - as extremely crucial for entrepreneurship. Strict adherence to 'pre-established' rules, considered as judgment based on common sense in our analysis, betrays a lack of sensitivity and even encourages immoral behaviours. They also assert that key features of such flexibility are moral imagination and sensitivity. Clarke and Holt (2010, p. 320) talk about the entrepreneurial dilemma as being a balance between external pressures and personal judgment. The authors claim that successful entrepreneurs can sustain their judgment and action even when they diverge from the common perception. These two works arrive at similar conclusions, even though actually they do not share the same ontology: the adherence to an external common way of feeling and to pre-established rules, i.e. the application of common sense, can be harmful if applied and followed without deeper discernment of uncertain contingencies (Dunham, 2010). 
Considering specifically our conceptual model and its elements as knowledge-cognitive, affective-external, and personal-reflective dimensions, we found a strong similarity to the effectual approach (Sarasvathy, 2001; Sarasvathy and Dew, 2005). For entrepreneurial studies effectual logic is a relatively new paradigm, which definitely opposes the basic assumptions of the so-called causal logic, i.e. traditional thoughts derived from economic theories. The main assumptions of effectual logic are compared to those of causal logic, given in parentheses here, in order to highlight the opposed ontologies: 1) creative vision about the future (versus predictive and controlling vision); 2) taking action considering the means of disposition (versus purely goalorientation); 3) risk and resources are evaluated in terms of affordable loss (versus focus on expected returns); 4) attitude towards stakeholders and orientation to partnership (versus competitive attitude); and 5) unexpected circumstances considered as opportunities to be leveraged (versus consideration as threats to be avoided $)^{10}$. In particular, Sarasvathy and Dew (2005) argue that the entrepreneurial process begins with three resources: the identity of the entrepreneur, the amount and the kind of knowledge possessed, and the network of agents with whom one can collaborate.

In a successive study the same authors reinterpret these three resources in terms of ethical challenges to be answered: What the entrepreneur knows, Who s/he is, and with Whom s/he collaborates (Dew and Sarasvathy, 2007). Undoubtedly these questions resemble our dimensions, although the effectuation model globally embraces entrepreneurship and the entrepreneurial process as a whole, going beyond the simple step of judgment.

The knowledge-cognitive dimension poses relevant issues for a deeper understanding of the abstract knowledge of entrepreneurs. In other words, this dimension supports individuals in managing their knowledge endowment, e.g. by indicating which part of such patrimony proves to be more relevant to the particular contingencies of the moment or suggesting actions to acquire missing elements. The externalaffective dimension takes care of the entrepreneur's relations and manages these interactions to understand others' feelings and expectations. Finally, the personal-reflective dimension channels the other considerations into a personal judgment 'appropriate' for the identity of the entrepreneur. This phase brings to light visionary and creative scenarios for future outcomes (Kraut, 1991). Yet in line with what we have said before, it has been found that expert entrepreneurs, here considered as successful, employ distinctive 
Ethical judgment and radical business changes: the role of entrepreneurial perspicacity

effectuation logic, i.e. our three dimensional model, to frame entrepreneurial problems more than any other approach (Dew et al., 2009).

\section{Narrative Case Study of a Successful Entrepreneur}

To conclude our work, we present the narratives about Geox Spa and its founder Mario Moretti-Polegato that may represent a case of employment of entrepreneurial perspicacity. Geox's success is publicly acknowledged $^{11}$ and self-evident just by considering the results that in less than 20 years the company developed from a start-up to a world leader in the shoes and fashion industry. Data collection came from a mix of sources such as financial reports, documental archives, interviews, newspapers, the company's website, and academic case studies about the company and its environment (Ciappei and Simoni, 2005; Sammarra and Belussi, 2006; Camuffo et al., 2008).

We acknowledge that this is a limitation of our paper because considerations are just inferred through a reconstruction of the story's evidences. Hence, we cannot assure that such judgments are univocally and directly related to the use of perspicacity. Nevertheless, the interpretation we made may be useful for further studies to employ our theory about entrepreneurial perspicacity and its dimensions.

With regard to Geox's history, we have paid special attention only to the start-up moment where uncertainty was extremely high and consequently perspicacity may have played a central role. The founder of Geox, Mario Moretti-Polegato, comes from a third-generation entrepreneurial family. After attaining a degree in Agricultural Science, he started his career as an entrepreneur in the family business that was mainly focused on the winegrower and wine-making industry. During that early period he developed his entrepreneurial passion for business and for the 'enjoyment' of creating something productive.

During a trip to Reno (Nevada), he decided to go hiking after a wine convention. The high temperature and arduous effort soon made walking unbearable. His rubber-soled shoes, despite being suitably designed for hiking, overheated his feet and made them sweat excessively. Therefore, in search of relief, he used a pocketknife and cut holes into the soles of his sneakers (Geox Press Map, 2012).

Since that experience, he became interested in this problem, especially after having worked out that no footwear producers had ever found a solution. The technical issue was how to combine at the same time in a sole the necessity for freshness, while keeping the feet dry preventing groundwater from coming in. Moretti- 
Ethical judgment and radical business changes: the role of entrepreneurial perspicacity

Polegato then spent three years studying and experimenting, and finally came up with a patent for the first model of Geox's shoes. The technology resolved the problem of rubber soles by using an integrated system of a perforated sole with a thin internal membrane, promoted as 'the shoes that breathe' ${ }^{12}$. However, the first search for a partner to develop an industrial production of the model was unsuccessful as all the major footwear manufacturers such as Nike, Adidas, Timberland, etc., turned down his proposal (Camuffo et al., 2008). Nonetheless, instead of abandoning the programme, Moretti-Polegato decided to carry on and start production in a small leather laboratory belonging to his family in the district of Montebelluna.

Another crucial element at the beginning of the activity was how to commit employees to such an uncertain project. Moretti-Polegato engaged five young employees, workers from the district, to supervise the strategic functions of the embryonic company. He promised great returns within a short time if they were prepared to take care of the venture. Moretti-Polegato, by avoiding an autocratic leadership style and paying particular attention to the empowerment process, developed in them a strong sense of affiliation and identification, which in turn assured a winning initial team for the company (Ciappei and Simoni, 2005).

At the moment of the commercial launch, Moretti-Polegato developed a smart entry strategy in order to approach an already saturated market: the shoe industry. The first model of these shoes was made for children and distributed free of charge to schools and other children's institutions. With this bottom-up process, the children's segment facilitated the consecutive entrance of Geox shoes to the mainstream market, where adults, parents, or relatives of those children were already familiar with the brand and the product. The marketing communication strategy during the launch was based on the technical characteristics of the product rather than simply appealing to the 'Italian style' (Camuffo et al., 2008). This strategy, quite untypical for Italian fashion companies, was adopted because Moretti-Polegato was convinced that his product would attract customers with 'real needs', more than those only interested in extremely trendy designs.

Considering this small narrative about the entrepreneur and the company, we have given evidence of salient aspects, interpreted in the light of our framework. At the beginning of his entrepreneurial journey, MorettiPolegato probably had experienced contrasting feelings and signals coming from the circumstances. 
His experience in the US signalled a 'real' need for users of rubber-soled shoes; however, producers were not showing any interest in that need or, even worse, they did not see the problem at all. His knowledgecognitive dimension probably began to ponder this opening set of alternatives and to reveal elements of dystonia in respect to his knowledge. Even if an entrepreneur coming from the wine-making industry could not directly apply his factual knowledge to the situation, his higher principles of entrepreneurial judgment may have awakened a sense of alertness for new opportunities.

After that, the external-affective dimension probably came into play. We can infer this from his engagement with his employees. Of course, as we have repeated during this study, behaviour is not the domain of judgment or of gnome. However, good behaviour, correctly ordered by PR in execution, is also the result of an initial 'good' judgment (S.Th, II ${ }^{\mathrm{ae}}$-IIae, q.48, a.1, q.51, a.1-4).

Finally, especially in the launch phase, we can conceive that a great role was played by the personalreflective dimension of perspicacity, which had judged as positive a partial disapplication of current paradigms. Both the entry and communication strategies prima facie may appear as counterfactual. First, despite a strong investment in technologies and innovation made by Geox during the start-up phase, the entrepreneur decided to enter into a less competitive, but also initially less remunerative, segment. With common sense, a leader would have avoided such a counterfactual course of action or, in other words, would have regarded such an alternative in a negative light. The circumstances indeed presented extremely uncertain revenue levels against a huge investment. However, this decision turned out to be wise; on the one hand it let final customers of Geox become familiar with the product through their children's experience; at the same time, dangerous business reactions from the incumbents of the industry were avoided thanks to a non-direct and not compelling foray into the main market. Secondly, the communication strategy deliberately avoided emphasis on a potential 'strength' of the company, i.e. the Italian style. This would probably have appealed to some segments of customers over the short term, but on the other hand it would have confused customers belonging to Geox's real target, i.e. people with a real need for 'smart comfort'.

\section{Conclusion}

This study aims to enrich the scholarly discourse of business ethics on the interpretation of PR in entrepreneurial activities. We have introduced new elements of reflection thanks to Aquinas' interpretation 
of PR and its potential parts, in particular gnome and synesis. These two secondary virtues share the same domain viz. the judgment but only the former, assuming exceptionality of the contingencies, can obtain fairer outcomes. The latter instead consists of judgments more oriented towards experience and is based on already consolidated rules and norms. Unfortunately, radical changes and uncertainty bring revolutions of paradigms and this may render consolidated routines useless.

Then, as a result of the semantic reconstruction of the meaning of gnome, we highlighted how a 'correct' entrepreneurial judgment should be performed. Specifically, we emphasised the three dimensions of our model, i.e., knowledge-cognitive, external-affective, and personal-reflective. The knowledge-cognitive dimension offers insights and hints about becoming aware of being confronted by an exceptional case. The external-affective dimension then stimulates sensations about potential outcomes proposed by the alternatives. Finally, the personal-reflective dimension allows entrepreneurs to develop multiple and flexible scenarios to counter prevailing paradigms. Judgments made using perspicacity as the 'trigger' of correct entrepreneurial orientation in turn lead to higher performance (Rauch et al., 2009; Covin and Lumpkin, 2011). A major reliance on entrepreneurial perspicacity in the composition of PR thus permits entrepreneurs advantageously to create value for the firm and for society while at the same time being themselves enriched and experiencing their lives flourishing (Cornwall and Naughton, 2003; George, 2003; Benedict XVI, 2009; Goodpaster, 2011). In this way, entrepreneurial work is 'good' not only in relation to positive outcomes but for the entrepreneurs themselves who become 'perfected' through their activities (MacIntyre, 1984).

This work makes different contributions to knowledge which are all related to the virtue of gnome. First we have applied this concept to business ethics, where, to the best of our knowledge, it was still missing. This concept, even though beyond the particular focus of our studies, can be used to address delicate situations of business and controversial ethical issues. We have also validated the idea that virtues are involved in the cognitive decision-making process (Arjoon, 2008, 2010; Melé, 2010). We individuate three practical elements to interpret how the judgment based on perspicacity may work. Also our interpretation can be used in combination with, and enlarged by, previous models which specifically involve virtues in their consideration (e.g. Bastons, 2008; Grassl, 2010). 
Ethical judgment and radical business changes: the role of entrepreneurial perspicacity

Obviously our paper has limitations, as our theses are untested in an empirical setting. The presentation of a narrative case study is not sufficient to support our claims with strong evidence. Further research is needed to address this gap, for example in an experimental setting, by presenting hypothetical situations to entrepreneurs. In this way, judgment based on perspicacity or common sense could emerge critically analysing the replies of the involved subjects.

\footnotetext{
${ }^{1}$ From now on we will use the word 'perspicacity' interchangeably with 'gnome' and the word 'common sense' interchangeably with 'synesis'. In particular, the Biblical Greek transliterations have been mainly maintained from a philosophical perspective, while in contexts of a more entrepreneurial nature we have tended to use the translated expressions.
}

${ }^{2}$ The debate on such partition has evolved during the centuries up today (for a recent evolution of the discipline see, Husserl, 1973; Simons, 1991; Smith and Smith, 1995). However, in this work we will take into account only the thoughts of Aquinas and the medieval perspective on the subject, despite the fact that this classification has evolved and been partially criticised. However, a long discussion on the proper assignation of gnome to PR is beyond the scope of this paper. Future works could study the problem solving process with a holistic approach in order to blend virtuously euboulia and synesis or gnome and PR.

${ }^{3}$ Entrepreneurial orientation is typically characterized either by a three-dimensional concept where keys factors are innovation, risk-taking, proactivity (Miller, 1983) or by a more complex model where also autonomy and aggressiveness are added to the original three key factors (Lumpkin and Dess, 1996; Covin and Lumpkin, 2011).

${ }^{4}$ The study of synesis and its applications is beyond the scope of this paper. However, a judgment of alternatives (iudicio electionis) based on common sense contributes to structure the balance of fair routines, and thus it is clearly necessary to achieve prosperity and sustainability of a business, especially in more stable phases.

${ }^{5}$ The entrepreneurs here considered as 'successful' are not 'categorically' better than their peers. Rather their faculties of judgment are more oriented by gnome than synesis and thus in the composition of their virtue of PR as a potential whole, gnome plays a relevant role. In practical terms, it has been proved that successful entrepreneurs employ an approach similar to our model of judgment (Dew et al., 2009), confirming the foundation of our claims. We are thankful to one of the anonymous reviewers for the comment on this aspect. 
${ }^{6}$ For a review of the topic, see the special issue of 2011 "The Encyclical-letter 'Caritas in Veritate': Ethical Challenges for Business", Journal of Business Ethics 100(supplement 1).

${ }^{7}$ This particular part of the study was possible thanks to the collaboration of some university lecturers in ancient and foreign languages (Biblical Greek, English, French, German, and Spanish) who have kindly participated in this project. Each lecturer offered suitable translations, either in English or in Italian, for the analysed paragraph. Then, the English lecturer together with the authors revised and corrected the nearest translations.

${ }^{8}$ We have found categories that may be similar to an extensive definition of PR (S.Th., II'-IIae, q. 48, a.1). However, we also defined the function of gnome with regarding to PR and the borders of the two. Gnome governs an intellective act without a final command/execution. For the sake of clarity, in the definition of our dimensions, we have also reported terminology taken from the 'Three-Dimensional wisdom scale' (Clayton and Birren, 1980; Ardelt, 2004). This scale attempts to measure three characteristics of wise people: cognitive as knowledgeable, experienced, intelligent, pragmatic, and observant; affective as understanding, empathic, peaceful, and gentle; and reflective as introspective and intuitive. This classification, in fundamental terms, seems to replicate our findings. However, this scale refers to PR in general, thus it could lead to misleading interpretations of our dimensions that instead only refer to gnome or perspicacity.

${ }^{9}$ The model suggests that the first step of the judgment based on perspicacity is moral reasoning followed by moral sensitivity. However, in recent evolutions of the pertinent literature, this sequential approach has been criticised (e.g. Haidt, 2001; Zhong, 2011). Moral sensitivity is seen as an almost 'instinctual' reaction that later is channelled into a more conscious discourse thanks to the moral reasoning. Regardless of what sequence is assumed to be true, this does not invalidate our model. Both insights, coming from moral reasoning and sensitivity, are then recomposed into the personal-reflective dimension that creates final scenarios for each alternative, forming the base of moral imagination (Carroll, 1980; Buchholz and Rosenthal, 2005).

${ }^{10}$ For a complete explanation of effectual logic, see Sarasvathy (2001) and Sarasvathy and Dew (2005).

${ }^{11}$ The entrepreneur was awarded the 'Italian Entrepreneur of the Year' in 2002. This event is sponsored and organized by the financial services company Ernst \& Young. The selection criteria usually are: entrepreneurial spirit, performance, strategic leadership, global environmental impact, innovation, and personal integrity. The 'Hall of Fame' of this event can be viewed at <www.ey.com> 
Ethical judgment and radical business changes: the role of entrepreneurial perspicacity

${ }^{12}$ For this patent and his continuous commitment to innovation, Moretti-Polegato was nominated for a life-time achievement award at the European Inventor award ceremony in 2012, sponsored by $C N B C$ in partnership with the Financial Times. 
Ethical judgment and radical business changes: the role of entrepreneurial perspicacity

\section{References}

Acevedo, A.: 2012, 'Personalist Business Ethics and Humanistic Management: Insights from Jacques Maritain’, Journal of Business Ethics 105(2), 197-219.

Alberti, A.: 2008, L’Arte del Vivere: Aspetti dell'Etica Aristotelica ed Epicurea (Il Nuovo Melangolo, Genoa).

Aquinas Thomas: 1947, Summa Theologiea, trans. Fathers of the English Dominican Province (Benzinger Press, New York).

Aquinas Thomas: 2010, Aquinas’ Summa Theologiae, trans. S. Loughlin (T\&T Clark International, New York).

Aquinas Thomas: 1951, Commentary on Aristotle's De Anima, trans. K. Foster and S. Humphries (Yale University Press, New Haven MA).

Aquinas Thomas: 1964, Commentary on the Nicomachean Ethics, trans. C. I. Litzinger (Henry Regnery Company, Chicago).

Ardelt, M.: 2004, 'Wisdom as Expert Knowledge System: A Critical Review of a Contemporary Operationalization of an Ancient Concept', Human Development 47, 257-285.

Argandoña, A.: 2011, ‘Beyond Contracts: Love in Firms’, Journal of Business Ethics 99(1), 77-85.

Aristotle: 1961, De Anima, trans. W. D. Ross (Clarendon Press, Oxford).

Aristotle: 1824, L'Ethique a Nicomaque, trans. F. Thurot (Editions Firmin Didot, Paris).

Aristotle: 1911, Die Nikomachische Ethik, trans. E. Rolfes (F. Meiner, Leipzig).

Aristotle: 1918, La Ética de Aristóles, trans. P. S. Abril (Real Academia de Ciencias Morales y Políticas, Madrid).

Aristotle: 1923, The Ethics of Aristotle, trans. J. E. C. Welldon (MacMillan \& Co., London) (original. ed., 1908).

Aristotle: 1931, Ética a Nicòmaco, trans. F.G. Palés (De L. Rubio, Madrid).

Aristotle: 1949, L’Etica Nicomachea, trans. G. Dal Sasso (Tipografie Del Seminario, Padua).

Aristotle: 1968, Nicomachean Ethics, trans. H. Rackham (Harvard University Press, Cambridge MA)

Aristotle: 1970, L'Ethique a Nicomaque, trans. R. A. Gauthier and J. Y. Jolif (Publications Universitaires, Louvain).

Aristotle: 1979, L'Ethique a Nicomaque, trans. J. Tricot (Vrin, Paris).

Aristotle: 1993, Etica Nicomachea, trans. C. Mazzarelli (Rusconi Libri, Milan).

Aristotle: 1994, Etica Nicomachea, trans. A. Plebe (CDE, Milan).

Aristotle: 1996, Etiche, trans. L. Caiani (UTET, Turin). 
Ethical judgment and radical business changes: the role of entrepreneurial perspicacity

Aristotle: 1998, Etica Nicomachea, trans. F. Bolino (Il Melangolo, Genoa).

Aristotle: 1998, Nicomachean Ethics, trans. W. D. Ross (Oxford University Press, Oxford).

Aristotle: 1999, Etica Nicomachea, trans. C. Natali (Ed. Laterza, Bari).

Aristotle: 2002, Etica Nicomachea, trans. M. Zanatta (BUR Rizzoli, Milan).

Aristotle: 2002, Nicomachean Ethics, trans. C. Rowe (Oxford University Press, Oxford UK).

Aristotle: 2008, Die Nikomachische Ethik, trans. A. Lasson (Ravensburg Grinverl, Munich).

Arjoon, S.: 2008, 'Reconciling Situational Social Psychology with Virtue Ethics', International Journal of Management Reviews 10(3), 221-243.

Arjoon, S.: 2010, 'Aristotelian-Thomistic Virtue Ethics, Emotional Intelligence and Decision-Making', Advances in Management 3(4), 7-13.

Arlig, A.: 2011, 'Medieval Mereology', in E. N. Zalta (eds.), The Stanford Encyclopaedia of Philosophy, Accessed on $20^{\text {th }}$ of June 2013. Available at http://plato.stanford.edu/archives/fall2011/entries/mereology-medieval

Bastons, M.: 2008, 'The Role of Virtues in the Framing of Decisions', Journal of Business Ethics 78(3), 389-400.

Benedict XVI: 2009, Encyclical Letter Caritas in Veritate. Accessed on $15^{\text {th }}$ of February 2012. Available at http://www.vatican.va/holy_father/benedict_xvi/encyclicals/documents/hf_ben-xvi_enc_20090629_caritas-in

veritate_en.htm

Boethius, A. M. S.: 1998, De Divisione. Critical Edition, Translation, Prolegomena and Commentary, trans. J. Magee (Brill, Leiden).

Bradley, D. J. M.: 1997, Aquinas on the Twofold Human Good (Catholic University Press, Washington DC).

Broadie, S.: 1991, Ethics with Aristotle (Oxford University Press, Oxford UK).

Buchholz, R. A. and S. B. Rosenthal: 2005, 'The Spirit of Entrepreneurship and the Qualities of Moral Decision Making', Journal of Business Ethics 60(3), 307-315.

Caiani, L.: 1998, Lettura all" "Etica Nicomachea” di Aristotele (UTET, Turin).

Cajetan, Thomas de Vio: 1981, Commentarius in Sancti Thomae Aquinatis, Summa Theologiea in Opera Omnia iussa edita Leonis XIII p.m. (Typographia polygotta, Rome).

Camuffo, A., A. Furlan, P. Romano and A. Vinelli: 2008, 'Breathing Shoes and Complementarities: Strategic Innovation in a Mature Industry', International Journal of Innovation Management 12(2), 139-160.

Carroll, A.: 1980, 'In Search of the Moral Manager', Business Horizons 30, 7-25.

Cessario, R.: 2002, The Virtues, or the Examined Life (Continuum, New York). 
Ethical judgment and radical business changes: the role of entrepreneurial perspicacity

Christensen, C. M. and J. L. Bower: 1996, 'Customer Power, Strategic Investment, and the Failure of Leading Firms', Strategic Management Journal 17(3), 197-218.

Ciappei, C. and C. Simoni: 2005, 'Drivers of New Product Success in the Italian Sport Shoe Cluster of Montebelluna', Journal of Fashion Marketing and Management 9(1), 20-42.

Clarke, J. and R. Holt: 2010, 'Reflective Judgment: Understanding Entrepreneurship as Ethical Practice', Journal of Business Ethics 94(3), 317-331.

Clayton, V. P. and J. E. Birren: 1980, 'The Development of Wisdom across the Life-Span: A Reexamination of an Ancient Topic', in P. B. Baltes and O. G. J. Brim (eds.), Life-Span Development and Behavior vol.3, (Academic Press, New York), pp. 103-135.

Cornwall, J. R. and M. J. Naughton: 2003, 'Who is the Good Entrepreneur? An Exploration within the Catholic Social Tradition', Journal of Business Ethics 44(1), 61-75.

Covin, J. G. and D. P. Slevin: 1991, 'A Conceptual Model for Entrepreneurial Firm Behaviour', Entrepreneurship Theory and Practice 16(1), 7-24.

Covin, J. G. and G. T. Lumpkin: 2011, 'Entrepreneurial Orientation Theory and Research: Reflections on a Needed Construct', Entrepreneurship Theory and Practice 35(5), 1042-2587.

D'Aveni, R. A. and I. C. MacMillan: 1990, 'Crisis and the Content of Managerial Communications: A Study of the Focus of Attention of Top Managers in Surviving and Failing Firms', Administrative Science Quarterly 35(4), 634-657. Dew, N. and S. D. Sarasvathy: 2007, 'Innovations, Stakeholders \& Entrepreneurship', Journal of Business Ethics 74(3), 267-283.

Dew, N., S. Read, S. D. Sarasvathy and R. Wiltbank: 2009, 'Effectual versus Predictive Logics in Entrepreneurial Decision-making: Differences between Experts and Novices’, Journal of Business Venturing 24(4), 287-309.

Dunham, L. C.: 2010, 'From Rational to Wise Action: Recasting Our Theories of Entrepreneurship', Journal of Business Ethics 92(4), 513-530.

Eggers J. P. and S. Kaplan: 2013, 'Cognition and Capabilities’, Academy of Management Annals 7(1), 293-338.

Ericsson, K. A. and N. Charness: 1994, 'Expert Performance', American Psychologist 49(8), 725-747.

Fazzi, R.: 1984, Il Governo d'Impresa vol. II (Giuffré, Milan).

Freeman, R. E.: 1994, ‘The Politics of Stakeholder Theory’, Business Ethics Quarterly 4(4), 409-421.

George, B.: 2003, Authentic Leadership: Rediscovering the Secrets of Creating Lasting Value (John Wiley and Sons, Hoboken, NJ). 
Ethical judgment and radical business changes: the role of entrepreneurial perspicacity

'Geox Press Map': 2012, edited by Geox Spa - Press Office. Accessed on $9^{\text {th }}$ of September 2012. Available at http://www.geox.biz/pdf/2012/Geox_press_map_3103.pdf

Gifford, S.: 1992, 'Allocation of Entrepreneurial Attention', Journal of Economic Behavior \& Organization 19(3), 265284.

Goodpaster, K. E.: 2011, 'Goods that Are Truly Good and Services that Truly Serve: Reflections on "Caritas in Veritate" ', Journal of Business Ethics 100(supplement 1), 9-16.

Grassl, W.: 2010, 'Aquinas on Management and its Development', Journal of Management Development 29(7/8), 706715.

Haidt, J.: 2001, 'The emotional Dog and its Rational Tail: A Social Intuitionist Approach to Moral Judgment', Psychological Review 108(4), 814-834.

Hartman, E. H.: 2008, 'Socratic Questions and Aristotelian Answers: A Virtue-Based Approach to Business Ethics', Journal of Business Ethics 78(3), 313-328.

Helfat, C. E., S. Finkelstein, W. Mitchell, M. A. Peteraf, H. Singh, D. J. Teece and S. G. Winter: 2007, Dynamic Capabilities. Understanding Strategic Change in the Organizations (Blackwell Publishing, Malden MA).

Huff, A. S.: 1990, Mapping Strategic Thought (John Wiley and Sons, New York).

Husserl, E.: 1973, Logical Investigation (Routledge, London) (original ed. 1900).

Kaplan, S.: 2008 ‘Framing Contests: Strategy Making under Uncertainty’, Organization Science 19(5), 729-752.

Kirzner, I.: 1973, Competition and Entrepreneurship (University of Chicago Press, Chicago).

Knight, F. H.: 1921, Risk, Uncertainty and Profit (Harper \& Row, New York).

Kor, Y. Y., J. T. Mahoney and S. C. Michael: 2007, 'Resources, Capabilities, and Entrepreneurial Perceptions', Journal of Management Studies 44(7), 1187-1212.

Kraut, R.: 1991, Aristotle on the Human Good (Princeton University Press, Princeton).

Krueger, N. F.: 2007, 'What Lies Beneath? The Experiential Essence of Entrepreneurial Thinking', Entrepreneurship Theory and Practice 31(1), 123-138.

Lumpkin, G.T. and G. Dess: 1996, 'Clarifying the Entrepreneurial Orientation Construct and Linking it to Performance', Academy of Management Review 21(1), 135-172.

MacIntyre, A.: 1984, After Virtue (University of Notre Dame Press, Notre Dame FR).

March, J. G.: 1991, 'Exploration and Exploitation in Organizational Learning', Organization Science 2(1), 71-87. 
Ethical judgment and radical business changes: the role of entrepreneurial perspicacity

Melé, D.: 2009, 'Integrating Personalism into Virtue-Based Business Ethics: The Personalist and the Common Good Principles', Journal of Business Ethics 88(1), 227-244.

Melé, D.: 2010, 'Practical Wisdom in Managerial Decision Making', Journal of Management Development 29(7), 637645 .

Melé, D., A. Argandoña and C. Sánchez-Runde: 2011, 'Facing the Crisis: Towards a New Humanistic Synthesis for Business', Journal of Business Ethics, 99(1), 1-4.

Miller, D.: 1983, 'The Correlates of Entrepreneurship in Three Types of Firms', Management Science 29(7), 770-791. Murphy, P. Rev.: 2006, 'Prudential Gnome, Right Judgments and Diagnostic test', Linacre Quarterly 73(2), 190-193. Nelson, R. and S. Winter: 1982, An Evolutionary Theory of Economic Change (Harvard University Press, Boston).

Nonaka, I. and R. Toyama: 2007, 'Strategic Management as Distributed Practical Wisdom (Phronesis)', Industrial and Corporate Change 16(3), 371-394.

Novak, M.: 1993, The Catholic Ethic and the Spirit of Capitalism (Free Press, New York).

Penrose, E. T.: 1959, The theory of the Growth of the Firm (Wiley, New York)

Perotto, L.: 1998, Commento all'Etica Nicomachea di Aristotele/S. Tommaso d'Aquino (ESD, Bologna).

Rauch, A., J. Wiklund, G. T. Lumpkin and M. Frese: 2009, 'Entrepreneurial Orientation and Business Performance: An Assessment of Past Research and Suggestions for the Future', Entrepreneurship Theory and Practice 33(3), 761-787.

Rodríquez-Luño, A.: 1997, 'La Virtù dell’Epicheia. Teoria, Storia e Applicazione (I). Dalla Grecia Classica fino a F. Suárez', Acta Philosophica VI, 197-236.

Sambrotta E.: 2009, ‘Azienda di Largo Respiro: Intervista a Mario Moretti-Polegato’, Dirigente 6(June), 6-11.

Sammarra, A. and F. Belussi: 2006, 'Evolution and Relocation in Fashion-led Italian Districts: Evidence from Two Case-studies', Entrepreneurship \& Regional Development 18(6), 543-562.

Sarasvathy, S. D.: 2001, 'Causation and Effectuation: Toward a Theoretical Shift from Economic Inevitability to Entrepreneurial Contingency', Academy of Management Review 26(2), 243-263.

Sarasvathy, S. D. and N. Dew: 2005, 'Toward a Technology of Foolishness: Alternative Logics Embodied in Entrepreneurial Action', Scandinavian Journal of Management 21(4), 385-406.

Schumpeter, J.: 1934, The Theory of Economic Development (Harvard University Press, Cambridge MA).

Simons, P. M.: 1991, 'Part/Whole II: Mereology Since 1900', in H. Burkhardt and B. Smith (eds.), Handbook of Metaphysics and Ontology (Philosophia, Munich), pp. 209-210. 
Ethical judgment and radical business changes: the role of entrepreneurial perspicacity

Sison, A. and F. J. Fontrodona: 2012, 'The Common Good of the Firm in the Aristotelian-Thomistic Tradition', Business Ethics Quarterly 22(2), 211-246.

Smith, B. and D. W. Smith: 1995, The Cambridge Companion to Husserl (Cambridge University Press, Cambridge).

Starbuck, W. H., A. Greve and B. L. T. Hedberg: 1978, 'Responding to Crisis', Journal of Business Administration 9(2), 112-137.

Sternberg, R. J.: 1990, 'Wisdom and its Relations to Intelligence and Creativity', in R. J. Sternberg (eds.), Wisdom: Its Nature, Origins, and Development (Cambridge University Press, Cambridge, UK), pp. 142-159.

Teece, D. J., G. Pisano and A. Shuen: 1997, 'Dynamic Capabilities and Strategic Management', Strategic Management Journal 18(7), 509-533.

Thaler, R. H.: 2000, 'From Homo Economicus to Homo Sapiens', Journal of Economic Perspectives 14(1), 133-141.

Walsh, J. P.: 1995, 'Managerial and Organizational Cognition: Notes from a Trip down Memory Lane', Organization Science 6(3), 280-321.

Westberg, D.: 1994, Right Practical Reason: Aristotle, Action, and Prudence in Aquinas (Oxford University Press, Oxford UK).

Westberg, D.: 1994-1995, 'The Relation between Positive and Natural Law in Aquinas', Journal of Law and Religion 11(1), 1-22.

Winter, S. G.: 2003, ‘Understanding Dynamic Capabilities', Strategic Management Journal 24(10), 991-995.

Zhong, C-B.: 2011, 'The ethical dangers of deliberative decision making', Administrative Science Quarterly 56(1), 125. 
Ethical judgment and radical business changes: the role of entrepreneurial perspicacity

Figure list

Figure 1 - Integral, Subjective, and Potential parts of Practical Reason

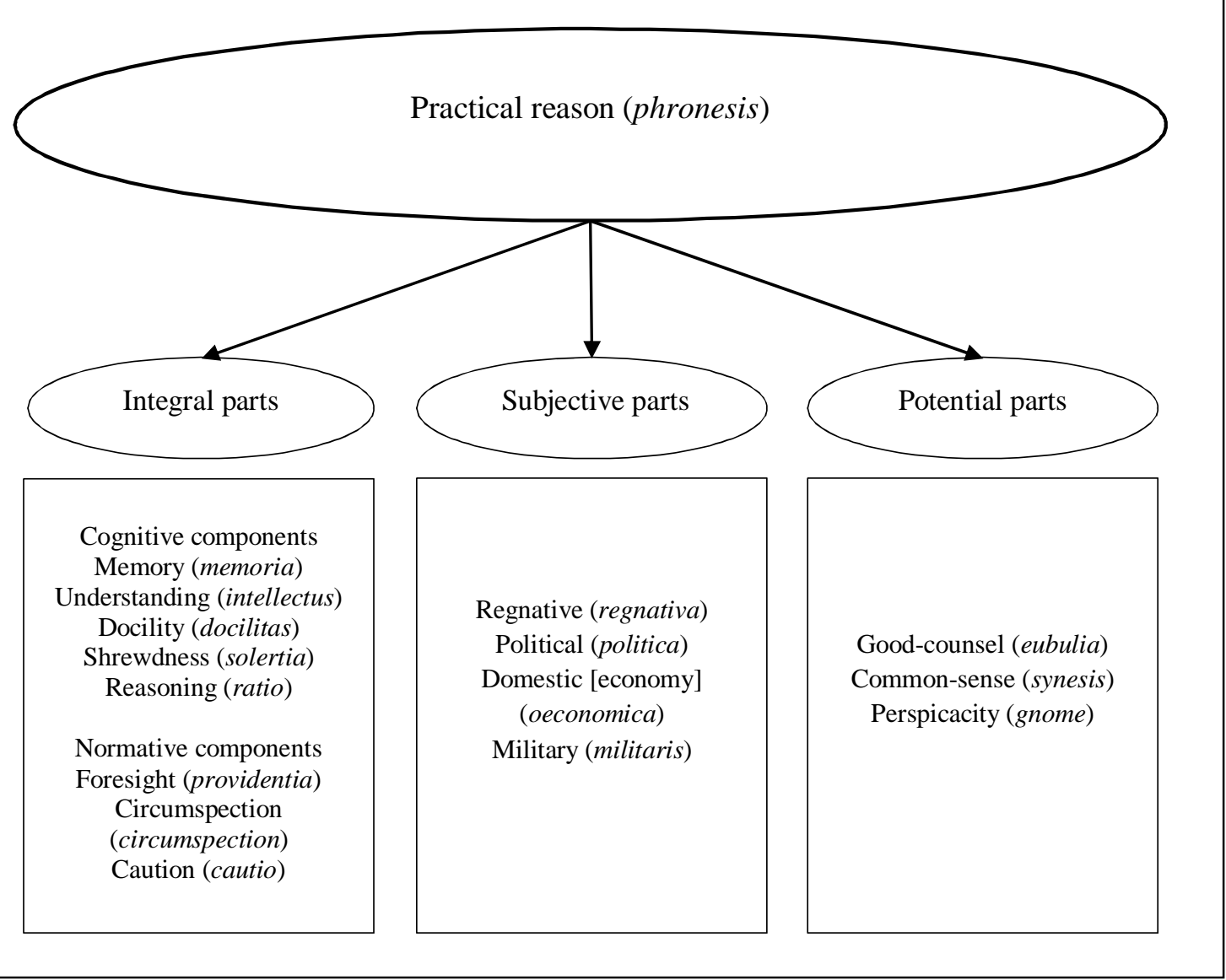


Ethical judgment and radical business changes: the role of entrepreneurial perspicacity

Figure 2 - Gnome and synesis: approaches to the act of judgment

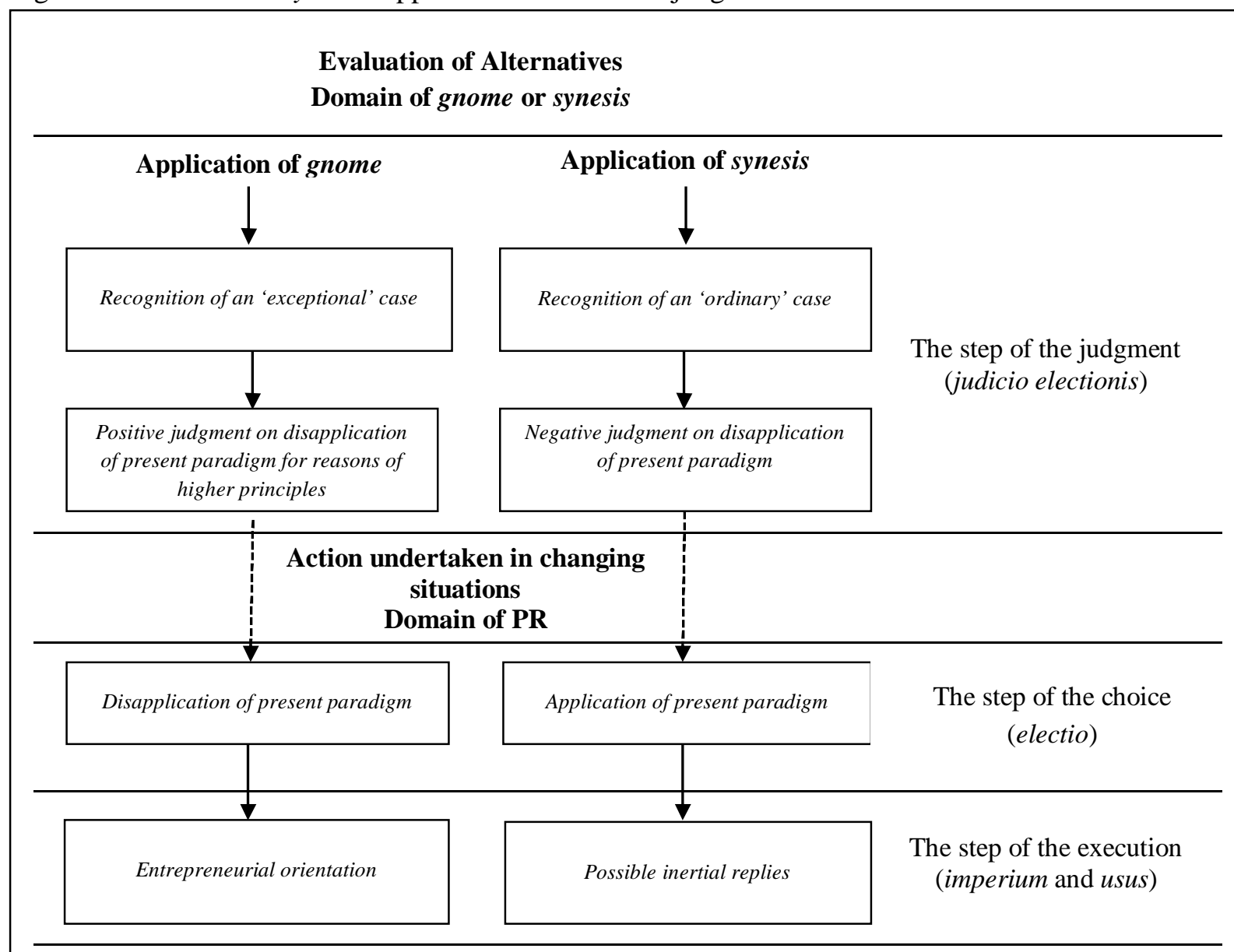


Ethical judgment and radical business changes: the role of entrepreneurial perspicacity

Figure 3 - The three dimensions of judgment made on the basis of perspicacity

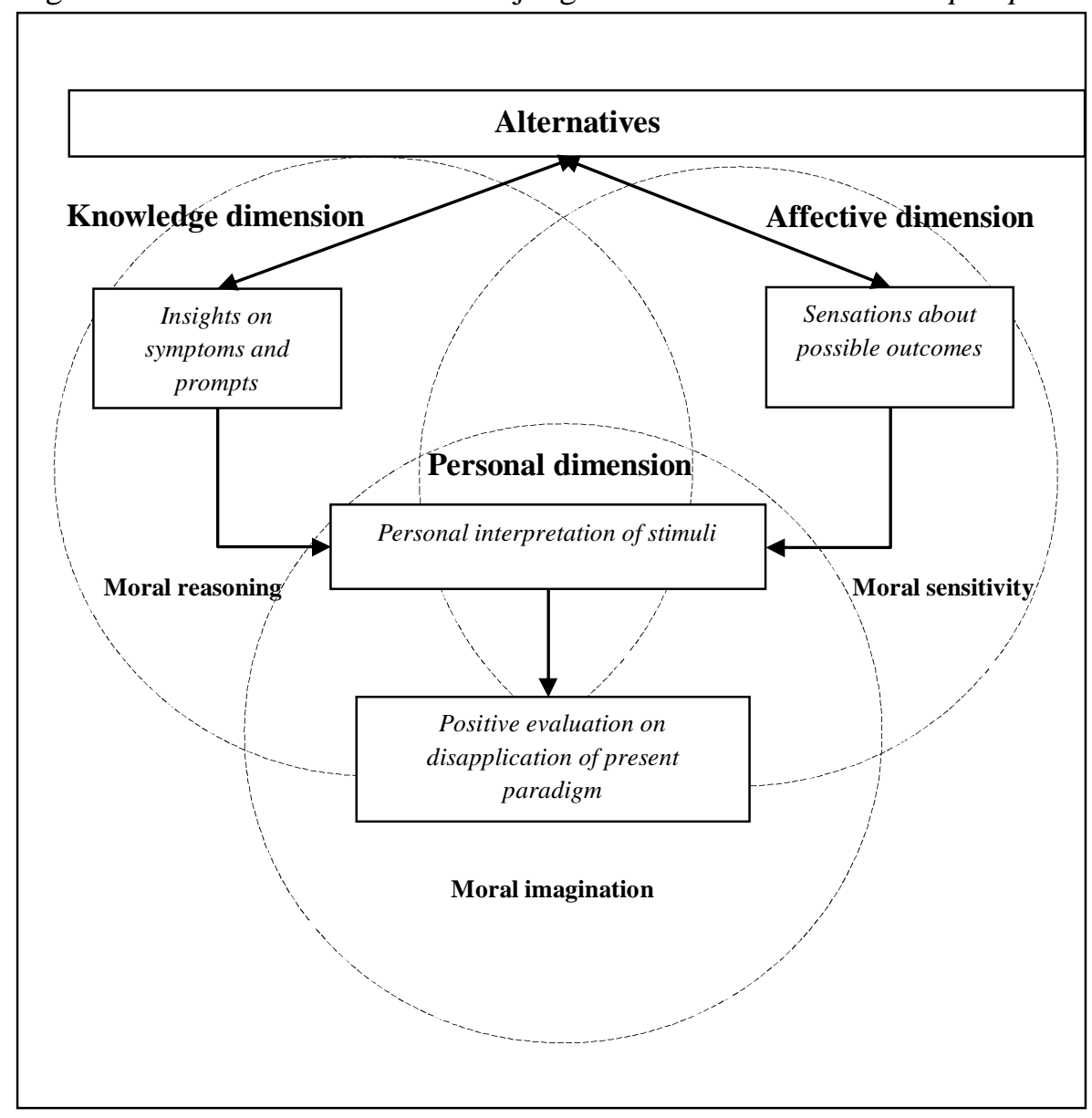


Ethical judgment and radical business changes: the role of entrepreneurial perspicacity

Table list

Table 1 - Reconstruction of the concept of gnome

\begin{tabular}{|c|c|c|}
\hline Title of the book & Translator/Author & Translation \\
\hline \multicolumn{3}{|r|}{ English } \\
\hline $\begin{array}{l}\text { Aristotle: 1968, } \\
\text { Nicomachean Ethics }\end{array}$ & $\begin{array}{l}\text { Harris Rackham } \\
\text { (integral text) }\end{array}$ & 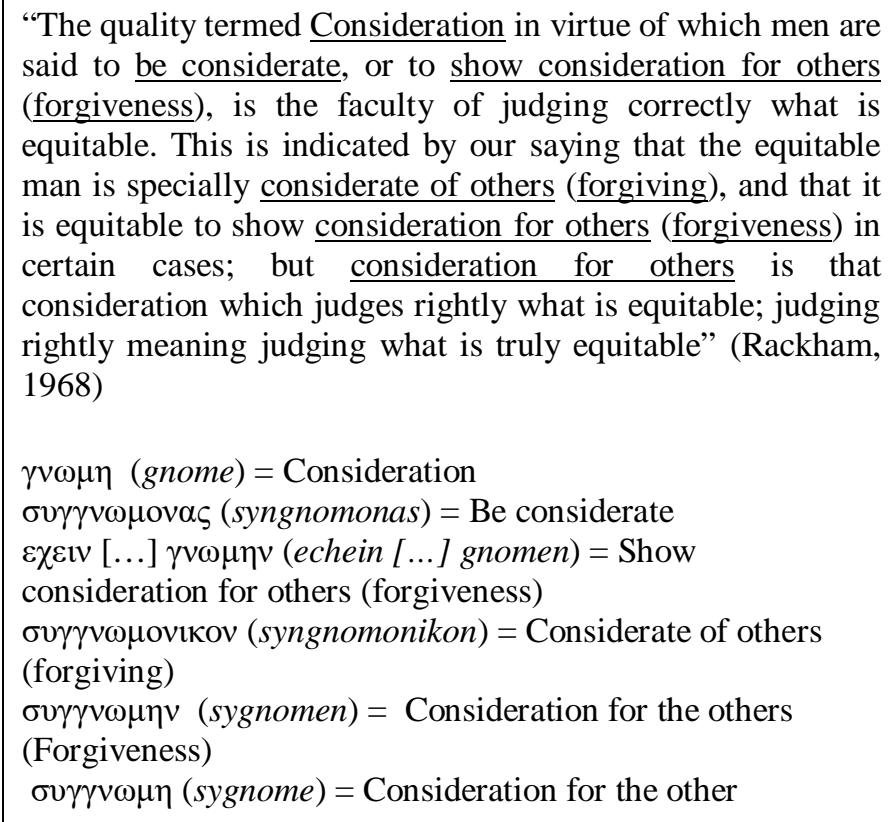 \\
\hline $\begin{array}{l}\text { Aristotle: } 1923, \\
\text { The Ethics of Aristotle }\end{array}$ & $\begin{array}{l}\text { James Edward } \\
\text { Cowell Welldon }\end{array}$ & $\begin{array}{l}\text { Judgment or Consideration } \\
\text { Considerate } \\
\text { Show consideration } \\
\text { Disposed to exercise kind consideration or forgiveness } \\
\text { Consideration or forgiveness } \\
\text { Forgiveness }\end{array}$ \\
\hline $\begin{array}{l}\text { Aristotle: 1998, } \\
\text { Nicomachean Ethics }\end{array}$ & $\begin{array}{l}\text { William David } \\
\text { Ross }\end{array}$ & $\begin{array}{l}\text { Judgment } \\
\text { Be sympathetic judges } \\
\text { Have judgment } \\
\text { Sympathetic judgment } \\
\text { Sympathetic judgment } \\
\text { Sympathetic judgment }\end{array}$ \\
\hline $\begin{array}{l}\text { Aristotle: } 2002 \text {, } \\
\text { Nicomachean Ethics }\end{array}$ & Christopher Rowe & $\begin{array}{l}\text { Sense } \\
\text { Having a shared sense, sympathetic } \\
\text { Have sense } \\
\text { Inclined towards sympathy } \\
\text { Sympathy } \\
\text { To be sympathetic }\end{array}$ \\
\hline
\end{tabular}




\begin{tabular}{|c|c|c|}
\hline \multicolumn{3}{|c|}{ Biblical Greek } \\
\hline 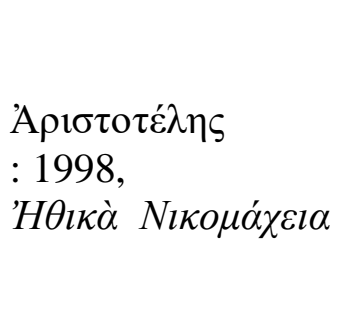 & $\begin{array}{l}\text { Direct translation } \\
\text { of a lecturer of } \\
\text { Ancient languages } \\
\text { (using the original } \\
\text { Greek text contained } \\
\text { in the version of } \\
\text { Ross) }\end{array}$ & $\begin{array}{l}\text { Comprehension/Discernment (Comprensione) } \\
\text { Indulgent (indulgenti) } \\
\text { That have comprehension/sympathy (che hanno } \\
\text { comprensione) } \\
\text { Inclined/Prone/Dispose towards indulgence/forgiveness } \\
\text { (disposti all'indulgenza) } \\
\text { Having indulgence/forgiveness (aver indulgenza) } \\
\text { Indulgence/Forgiveness (indulgenza) }\end{array}$ \\
\hline \multicolumn{3}{|r|}{ French } \\
\hline $\begin{array}{l}\text { Aristote: } 1824, \\
\text { L'Ethique à } \\
\text { Nicomaque }\end{array}$ & François Thurot & $\begin{array}{l}\text { Judgment/Discretion (jugement) } \\
\text { Judicious (judicieux) } \\
\text { Good sense (bon sens) } \\
\text { Indulgent (indulgent) } \\
\text { Character/Characteristic of indulgence/forgiveness (caractère } \\
\text { d'indulgence) } \\
\text { Indulgence/Forgiveness (indulgence) }\end{array}$ \\
\hline $\begin{array}{l}\text { Aristote: } 1970, \\
\text { L'Ethique à } \\
\text { Nicomaque }\end{array}$ & $\begin{array}{l}\text { Rene Antoine } \\
\text { Gauthier - Jean } \\
\text { Yves Jolif }\end{array}$ & $\begin{array}{l}\text { Good Sense (bon sens) } \\
\text { Benevolent (bienveillantes) } \\
\text { Show (proof of) kindness/goodness (font prévue de bonté) } \\
\text { Inclined/Prone/Dispose towards kindness/goodness (enclin à } \\
\text { la bonté) } \\
\text { Be able to show (proof of) kindness/goodness (savoir faire } \\
\text { prévue de bonté) } \\
\text { [...] (word is not reported) }\end{array}$ \\
\hline $\begin{array}{l}\text { Aristote: } 1979 \text {, } \\
\text { L'Ethique à } \\
\text { Nicomaque }\end{array}$ & Jules Tricot & $\begin{array}{l}\text { Judgment/Discretion (jugement) } \\
\text { Good judgment (bon jugement) } \\
\text { Have judgment/discretion (ont du jugement) } \\
\text { Sympathetically/Favourably disposed towards others } \\
\text { (favorablement disposé pour autrui) } \\
\text { Tolerance/Broad-mindedness (largeur d'esprit) } \\
\text { Tolerance/Broad-mindedness (largeur d'esprit) }\end{array}$ \\
\hline \multicolumn{3}{|r|}{ German } \\
\hline $\begin{array}{l}\text { Aristotele: } 1911, \\
\text { Die Nikomachische } \\
\text { Ethik }\end{array}$ & Eugen Rolfes & $\begin{array}{l}\text { Gnome, Discretion or Distinction (Gnome, Diskretion oder } \\
\text { Unterscheidung) } \\
\text { Discrete/Sober people (diskrete Personen) } \\
\text { Have/Possess discretion (besitzen Diskretion) } \\
\text { Especially prone (Excellent tendency) to indulgence/leniency } \\
\text { (neigen vorzüglich zur Nachsicht) } \\
\text { Indulgence/Leniency/Clemency (Nachsicht) } \\
\text { Indulgence/Leniency/Clemency (Nachsicht) }\end{array}$ \\
\hline $\begin{array}{l}\text { Aristotele: } 2008 \text {, } \\
\text { Die Nikomachische } \\
\text { Ethik }\end{array}$ & Adolf Lasson & $\begin{array}{l}\text { Well-intentioned/disposed sentiments/attitude } \\
\text { (wohlmeinende Gesinnung) } \\
\text { Sage/Good-minded (wohldenkender) } \\
\text { Wise man (einsichtiger Mann) } \\
\text { Well-intentioned/disposed (wohlmeinend) }\end{array}$ \\
\hline
\end{tabular}


Ethical judgment and radical business changes: the role of entrepreneurial perspicacity

\begin{tabular}{|c|c|c|}
\hline & & $\begin{array}{l}\text { Indulgence/Leniency/Clemency (Nachsicht) } \\
\text { Indulgent/Lenient/Clement judgment (nachsichtige } \\
\text { Beurteilung) }\end{array}$ \\
\hline \multicolumn{3}{|r|}{ Italian } \\
\hline $\begin{array}{l}\text { Aristotele: } 1949, \\
\text { L'etica Nicomachea }\end{array}$ & Giacomo Dal Sasso & $\begin{array}{l}\text { Gnome } \\
\text { Respectable/Moderate (perbene discreti) } \\
\text { That have moderation/discretion (hanno discretezza) } \\
\text { Sympathetic/Understanding (comprensivo) } \\
\text { Comprehension/Sympathy (comprensione) } \\
\text { Comprehension/Sympathy (comprensione) }\end{array}$ \\
\hline $\begin{array}{l}\text { Aristotele: } 1994, \\
\text { Etica Nicomachea }\end{array}$ & Armando Plebe & $\begin{array}{l}\text { Capability of discernment (facoltà di discernimento) } \\
\text { Moderate (discrete) } \\
\text { Capability of discernment (facoltà di discernimento) } \\
\text { Sympathetic/Understanding (comprensivo) } \\
\text { Comprehension/Sympathy (comprensione) } \\
\text { Comprehension/Sympathy (comprensione) }\end{array}$ \\
\hline $\begin{array}{l}\text { Aristotele: } 1993, \\
\text { Etica Nicomachea }\end{array}$ & Claudio Mazzarelli & $\begin{array}{l}\text { Comprehension/Discernment (comprensione) } \\
\text { Indulgent (indulgent) } \\
\text { That have comprehension (che hanno comprensione) } \\
\text { Inclined/Prone/Dispose towards indulgence/forgiveness } \\
\text { (disposto all'indulgenza) } \\
\text { Having indulgence/forgiveness (avere indulgenza) } \\
\text { Indulgence/Forgiveness (indulgenza) }\end{array}$ \\
\hline $\begin{array}{l}\text { Aristotele: 1996, } \\
\text { Etiche }\end{array}$ & Lucia Caiani & $\begin{array}{l}\text { Good Sense (buon senso) } \\
\text { Indulgent (indulgenti) } \\
\text { Have good sense (hanno buon senso) } \\
\text { Indulgent (indulgente) } \\
\text { Having indulgence/forgiveness (avere indulgenza) } \\
\text { Indulgence/Forgiveness (indulgenza) }\end{array}$ \\
\hline $\begin{array}{l}\text { Lucia Caiani: } 1998 \text {, } \\
\text { Lettura all' "Etica } \\
\text { Nicomachea" di } \\
\text { Aristotele }\end{array}$ & Lucia Caiani & $\begin{array}{l}\gamma v \omega \mu \eta \text { (Gnome) } \\
\text { Disposition by which one is called indulgent (unique } \\
\text { translation of two words) (disposizione per la quale si è detti } \\
\text { indulgenti) } \\
\text { Inclined/Prone/Dispose towards indulgence/forgiveness } \\
\text { (incline all'indulgenza) } \\
\text { Having indulgence/forgiveness (avere indulgenza) }\end{array}$ \\
\hline $\begin{array}{l}\text { Aristotele: } 1999, \\
\text { Etica Nicomachea }\end{array}$ & Carlo Natali & $\begin{array}{l}\text { Consideration (considerazione) } \\
\text { Reasonable/Sensible (ragionevoli) } \\
\text { Having comprehension/sympathy (abbiamo comprensione) } \\
\text { Sympathetic/Understanding (comprensivo) } \\
\text { Comprehension/Sympathy (comprensione) } \\
\text { Comprehension/Sympathy (comprensione) }\end{array}$ \\
\hline $\begin{array}{l}\text { Aristotele: } 2002, \\
\text { Etica Nicomachea }\end{array}$ & Marcello Zanatta & $\begin{array}{l}\text { Good sense (buon senso) } \\
\text { Indulgent (indulgenti) } \\
\text { That have good sense (che hanno buon senso) }\end{array}$ \\
\hline
\end{tabular}


Ethical judgment and radical business changes: the role of entrepreneurial perspicacity

\begin{tabular}{|l|l|l|}
\hline \multicolumn{2}{|l|}{} & \multicolumn{1}{|l|}{$\begin{array}{l}\text { Inclined/Prone/Dispose towards indulgence/forgiveness } \\
\text { (incline all'indulgenza) } \\
\text { Having indulgence/forgiveness (avere indulgenza) } \\
\text { Indulgence (indulgenza) }\end{array}$} \\
\hline & \multicolumn{1}{|c|}{ Spanish } \\
\hline $\begin{array}{l}\text { Aristóles: } 1918, \\
\text { La Ética de Aristóles }\end{array}$ & Pedro Simón Abril & $\begin{array}{l}\text { Judgment or Opinion (sentencia o parecer) } \\
\text { Have good sense/right judgment (tienen buen parecer) } \\
\text { Judicious/Well-disposed men (hombres de buen parecer) } \\
\text { Benign/Mild and merciful/compassionate (benigno y } \\
\text { misericordioso) } \\
\text { Having mercy/compassion (tener misericordia) } \\
\text { Mercy/Compassion or Forgiveness/Clemency (misericordia o } \\
\text { perdón) }\end{array}$ \\
\hline $\begin{array}{l}\text { Aristóles: 1931, } \\
\text { Ética a Nicòmaco }\end{array}$ & $\begin{array}{l}\text { Francisco Gallach } \\
\text { Palés }\end{array}$ & $\begin{array}{l}\text { Judgment/Sense/Reason (juicio) } \\
\text { Be good/well-disposed judges (son buenos jueces) } \\
\text { Have judgment/sense/reason (tienen juicio) } \\
\text { Men with good sense/good judgment, reasonable men } \\
\text { hombres de buen juicio) } \\
\text { Goodness/Kindness of judging (bondad de juicio) } \\
\text { Good sense/good judgment (buen juicio) }\end{array}$ \\
\hline
\end{tabular}


Ethical judgment and radical business changes: the role of entrepreneurial perspicacity

Table 2 - Summary of three dimensions of gnome

\begin{tabular}{|c|c|c|}
\hline Dimension & Main Word(s) & Means \\
\hline $\begin{array}{l}\text { Knowledge dimension } \\
\text { (Cognitive })\end{array}$ & $\gamma \nu \omega \mu \eta$ (gnome) & $\begin{array}{l}\text { Capability of discernment; Comprehension; Consideration; } \\
\text { Discernment; Good judgment; Good sense; Judgment; } \\
\text { Reason; Sense }\end{array}$ \\
\hline $\begin{array}{l}\text { External dimension } \\
\text { (Affective) }\end{array}$ & $\begin{array}{c}\sigma v \gamma \gamma v \omega \mu \eta(v) \\
(\text { sygnome/sygnomen })\end{array}$ & $\begin{array}{l}\text { Broad-mindedness; Character of indulgence or forgiveness; } \\
\text { Clemency; Clement judgment; Compassion; Comprehension; } \\
\text { Consideration for others; Consideration; Forgiveness; } \\
\text { Goodness of judging; Honesty; Indulgence; Indulgent } \\
\text { judgment; Kindness of judging; Leniency Lenient judgment; } \\
\text { Loyalty; Mercy; Sympathetic judgment; Sympathy; } \\
\text { Tolerance; Well-disposed sentiments; Well-intentioned } \\
\text { attitude }\end{array}$ \\
\hline $\begin{array}{l}\text { Personal dimension } \\
\quad \text { (Reflective) }\end{array}$ & 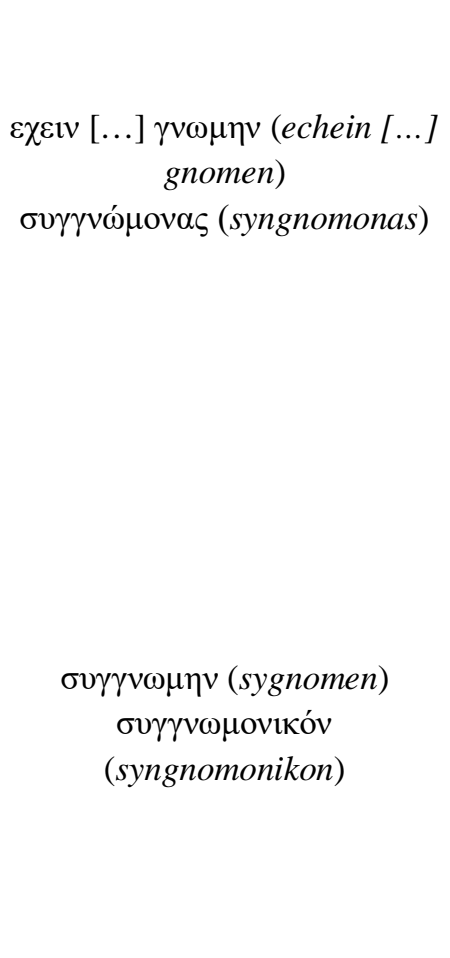 & $\begin{array}{l}\text { Personal ability to judge (personal interpretation of stimuli } \\
\text { coming from knowledge/cognitive dimension) } \\
\text { Be considerate; Be honest; Discrete; Good-minded; Have } \\
\text { discretion; Have judgment; Have moderation; Have reason; } \\
\text { Have right judgment; Have sense; Having a shared sense; } \\
\text { Honest; Judicious; Moderate; Reasonable men; Respectable; } \\
\text { Sage; Sober; Wise man } \\
\text { Personal ability to relate to others (personal interpretation of } \\
\text { stimuli coming from external/affective dimension) } \\
\text { Be good judges; Be sympathetic judges; Be well-disposed } \\
\text { judges; Benevolent; Benign; Compassionate; Considerate of } \\
\text { others; Disposed to exercise kind consideration; Disposition } \\
\text { by which one is called indulgent; Especially prone or } \\
\text { Excellent tendency to indulgence; Fair person; Favourably } \\
\text { disposed towards others; Forgiving; Inclined towards } \\
\text { sympathy; Have compassion; Have comprehension; Have } \\
\text { forgiveness; Have indulgence; Have mercy, Have sympathy; } \\
\text { Inclined, Prone or Disposed towards forgiveness or } \\
\text { indulgence; Indulgent; Loyal; Merciful; Mild; Sensible; Show } \\
\text { and be able to show proof of kindness; Show consideration } \\
\text { for others; Sympathetic; Sympathetically disposed towards } \\
\text { others; Understanding; Well-disposed; Well-intentioned }\end{array}$ \\
\hline
\end{tabular}

